The University of Maine

DigitalCommons@UMaine

Marine Sciences Faculty Scholarship

School of Marine Sciences

$1-1-2004$

\title{
The role of seawater constituents in light backscattering in the ocean
}

\author{
Dariusz Stramski \\ Marine Physical Laboratory \\ Emmanuel Boss \\ University of Maine, emmanuel.boss@maine.edu \\ Darek Bogucki \\ Rosenstiel School of Marine and Atmospheric Science \\ Kenneth J. Voss \\ University of Miami
}

Follow this and additional works at: https://digitalcommons.library.umaine.edu/sms_facpub

Part of the Marine Biology Commons

\section{Repository Citation}

Stramski, Dariusz; Boss, Emmanuel; Bogucki, Darek; and Voss, Kenneth J., "The role of seawater constituents in light backscattering in the ocean" (2004). Marine Sciences Faculty Scholarship. 155. https://digitalcommons.library.umaine.edu/sms_facpub/155

This Article is brought to you for free and open access by DigitalCommons@UMaine. It has been accepted for inclusion in Marine Sciences Faculty Scholarship by an authorized administrator of DigitalCommons@UMaine. For more information, please contact um.library.technical.services@maine.edu. 


\title{
The role of seawater constituents in light backscattering in the ocean
}

\author{
Dariusz Stramski ${ }^{\text {a,*}, ~ E m m a n u e l ~ B o s s ~}{ }^{b}$, Darek Bogucki ${ }^{c}$, Kenneth J. Voss ${ }^{\text {d }}$ \\ a Marine Physical Laboratory, Scripps Institution of Oceanography, University of California at San Diego, \\ La Jolla, CA 92093-0238, USA \\ ${ }^{\mathrm{b}}$ University of Maine, School of Marine Sciences, 5741 Libby Hall, Orono, ME 04469-5741, USA \\ ${ }^{\mathrm{c}}$ University of Miami, Rosenstiel School of Marine and Atmospheric Science, Division of Applied Marine Physics, \\ 4600 Rickenbacker Cswy, Miami, FL 33149-1098, USA \\ ${ }^{\mathrm{d}}$ University of Miami, Department of Physics, Coral Gables, FL 33124, USA
}

Received 3 November 2003; revised 4 July 2004; accepted 9 July 2004

Available online 19 August 2004

\begin{abstract}
The significance of light backscattering in the ocean is wide ranging, especially in optical remote sensing. However, the complexity of natural seawater as an optical medium often obscures the measured optical signals to the point that our present-day interpretation and detailed understanding of major sources of backscattering and its variability in the ocean are uncertain and controversial. Here we review the roles played by various seawater constituents in light backscattering and we address a question of 'missing' backscattering. Historically, this question has resulted from a hypothesis that under non-bloom conditions in the open ocean, phytoplankton make a significantly smaller contribution to the particulate backscattering coefficient than to the particulate (total) scattering coefficient. By discussing the backscattering properties and potential contributions of the various water constituents (colloids, bacteria, phytoplankton, biogenic detritus, minerogenic particles, bubbles), we show that due to substantial variability in water composition, different types of constituents can explain the 'missing' backscattering. Under typical non-bloom conditions in the open ocean, the small-sized non-living particles appear to be the most important because of their high abundance relative to other particle types. These particles are believed to be primarily of organic origin but an important role of minerogenic particles cannot be excluded. Still, in the very clear ocean water the backscattering by water molecules themselves can contribute as much as $80 \%$ to the total backscattering coefficient in the blue spectral region. The general scenario of the dominance of molecules and small-sized particles can, however, be readily perturbed due to changes in local conditions. For example, bubbles entrained by breaking waves can intermittently dominate the backscattering at shallow depths below the sea surface, the calcifying phytoplankton (coccolithophores) producing calcite scales of high refractive index can dominate if present in sufficient concentration, and other plankton species can dominate during blooms. The role of

\footnotetext{
* Corresponding author. Tel.: +1 858534 3353; fax: +1 8585347641 .

E-mail addresses: stramski@mpl.ucsd.edu (D. Stramski), emmanuel.boss@maine.edu (E. Boss), dbogucki@rsmas.miami.edu (D. Bogucki), voss@physics.miami.edu (K.J. Voss).
} 
phytoplankton could be generally greater than commonly assumed given the fact that real cells backscatter more light than predicted from homogeneous sphere models. In addition, high refractive index mineral particles can dominate in many coastal areas, and perhaps also in some open ocean areas during events of atmospheric dust deposition. It is likely that the different scenarios are quite widespread and frequent. Further improvements in quantitative understanding of the variability in light backscattering and its sources require an increased effort in basic research to better characterize the optical properties of the various seawater constituents and the variability in the detailed composition of seawater. Seawater is a complex optical medium containing a great variety of particle types and soluble species that vary in concentration and composition with time and location in the ocean, so ocean optics science must progress beyond the traditional overly simplified description, which has been based only on a few constituent categories defined broadly as molecular water, suspended particles (phytoplankton and non-algal particles), and dissolved organic matter.

(c) 2004 Elsevier Ltd. All rights reserved.

Keywords: Ocean optics; Optical properties; Seawater; Light scattering; Backscattering coefficient; Volume scattering function

\section{Contents}

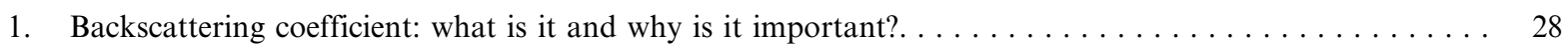

2. General considerations on light backscattering in the ocean $\ldots \ldots \ldots \ldots \ldots \ldots \ldots \ldots \ldots \ldots \ldots$

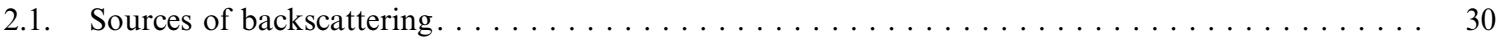

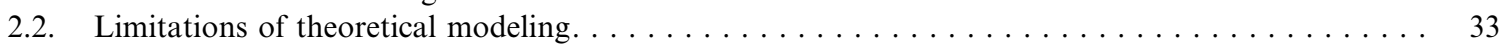

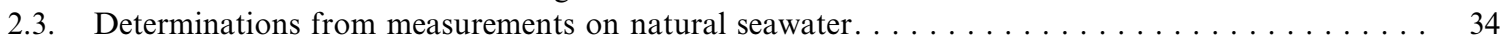

2.4. Determinations for specific types of marine particles $\ldots \ldots \ldots \ldots \ldots \ldots \ldots \ldots \ldots \ldots \ldots$

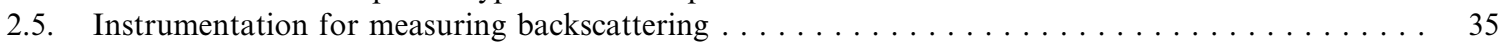

3. The roles of various seawater constituents in light backscattering $\ldots \ldots \ldots \ldots \ldots \ldots \ldots \ldots \ldots \ldots$

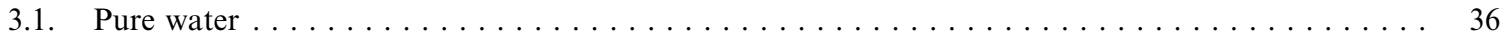

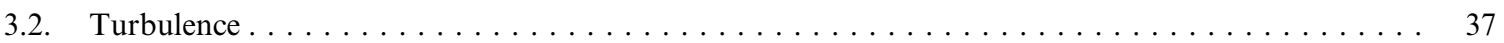

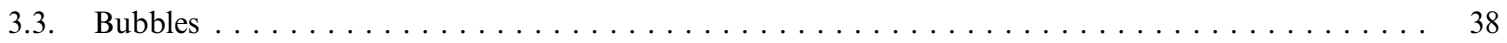

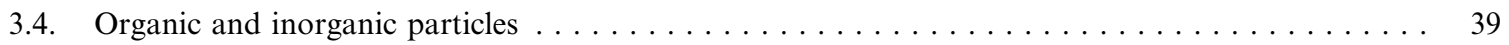

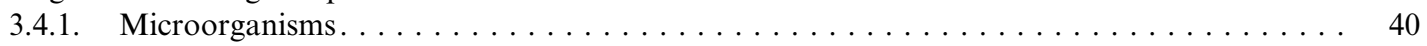

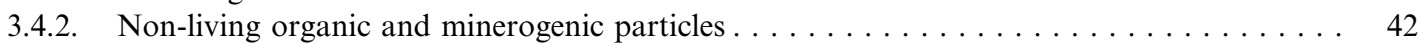

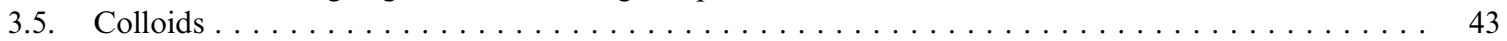

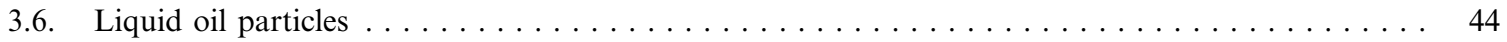

4. Backscattering as a proxy for particulate organic matter, particle composition, and size $\ldots \ldots \ldots \ldots$

5. The 'missing' backscattering enigma and future work $\ldots \ldots \ldots \ldots \ldots \ldots \ldots \ldots \ldots \ldots \ldots \ldots$

Acknowledgements . . . . . . . . . . . . . . . . . . 49

References. . . . . . . . . . . . . 50

\section{Backscattering coefficient: what is it and why is it important?}

When light propagates through ocean water, it interacts with molecules and particles of the medium primarily through elastic scattering of photons (change in the direction of propagation without a change in the 
photon frequency/energy) and absorption of photons (conversion of photon energy to other forms of energy such as heat or chemical energy). Other secondary interactions include inelastic (transpectral) processes such as fluorescence by dissolved organic matter and phytoplankton pigments, and Raman scattering by the water molecules. The two fundamental inherent optical properties (IOPs) of seawater which quantify the elastic scattering and absorption processes are the spectral volume scattering function, $\beta(\psi, \lambda)$ or VSF, and the spectral absorption coefficient, $a(\lambda)$. These (and other) IOPs of seawater are determined by additive scattering or absorption contributions associated with water molecules and the various dissolved and particulate constituents of seawater.

For a given light wavelength $\lambda, \beta(\psi, \lambda)$ describes the scattered radiant intensity into a scattering angle $\psi$ per unit irradiance of the incident unpolarized beam of light per unit volume of water (see Mobley, 1994, 1995 for review of current terminology, notation, and definitions in hydrologic optics). The theoretical definition of $\beta(\psi, \lambda)$ requires that the scattering volume approaches an infinitesimally small volume but, in practice, the measurement volume is typically from a fraction of $\mathrm{cm}^{3}$ to several $\mathrm{cm}^{3}$. Integrating $\beta(\psi, \lambda)$ over back directions, $\pi / 2 \leqslant \psi \leqslant \pi$, yields the backscattering coefficient $b_{\mathrm{b}}(\lambda)$ :

$$
b_{\mathrm{b}}(\lambda)=2 \pi \int_{\pi / 2}^{\pi} \beta(\psi, \lambda) \sin \psi \mathrm{d} \psi
$$

This definition assumes that scattering in natural waters is azimuthally symmetric about the incident direction (hence the factor $2 \pi$ ) of the unpolarized light beam. The scattering of a natural sunlight beam by a collection of randomly oriented molecules and particles in the ocean water roughly satisfies this assumption. The integration over all directions, $0 \leqslant \psi \leqslant \pi$, gives the total scattering coefficient, $b(\lambda)$. The ratio $\tilde{b}_{\mathrm{b}}(\lambda)=b_{\mathrm{b}}(\lambda) / b(\lambda)$ is referred to as the backscattering ratio (or backscattering fraction). The quantity $\tilde{\beta}(\psi, \lambda)=\beta(\psi, \lambda) / b(\lambda)$ is the scattering phase function, which provides a convenient measure of the angular distribution of scattered intensity regardless of the overall magnitude of scattering. The integration of $\tilde{\beta}(\psi, \lambda)$ over back directions yields $\tilde{b}_{\mathrm{b}}(\lambda)$. It must be noted that the discussion of polarization properties of light scattering is beyond the scope of this paper. The succinct review of the polarization of light in the ocean is given in Kattawar (1994).

In the area of modeling the radiative transfer in the ocean, the volume scattering function $\beta(\psi, \lambda)$ or the scattering phase function $\tilde{\beta}(\psi, \lambda)$ is needed as one of the input IOPs. The use of different phase functions of marine particles in numerical simulations of the light fields within the ocean or leaving the ocean implies the use of different values of the backscattering ratio. Examples of phase functions that have been used in such radiative transfer simulations include the phase functions numerically generated from Mie scattering theory (e.g., Mobley \& Stramski, 1997; Stramski \& Mobley, 1997), the phase functions based on measured VSFs (e.g., Petzold, 1972), and analytical phase functions that offer mathematical simplicity with significant degree of physical realism (e.g., Fournier \& Forand, 1994; Haltrin, 1999; Henyey \& Greenstein, 1941; Kattawar, 1975). Mobley, Sundman, and Boss (2002) compared several particulate phase functions used in radiative transfer simulations and concluded that it is crucial that the phase function has the correct particulate backscattering ratio. They also proposed an algorithm to generate analytic Fournier-Forand phase functions having any desired particulate backscattering ratio within a realistic range for marine particulate assemblages from a fraction of a percent to several percent.

The spectral backscattering coefficient $b_{\mathrm{b}}(\lambda)$ is of primary importance to applications of optical remote sensing in oceanography. These applications are typically based on observations of ocean color from spaceborne or airborne optical sensors that detect natural light backscattered within the ocean surface layer. Ocean color is essentially the spectrum of light leaving the ocean, normalized to the light incident on ocean surface. The ocean color can be quantified in terms of irradiance reflectance, $R(\lambda)$, or remote-sensing reflectance, $R_{\mathrm{rs}}(\lambda)$, which provide measures of the ratio of upwelling to downwelling light at the water surface (e.g., Mobley, 1994). To first approximation, the ocean reflectance varies as the ratio of the backscattering 
coefficient, $b_{\mathrm{b}}(\lambda)$, to absorption coefficient, $a(\lambda)$, of seawater (e.g., Gordon, Brown, \& Jacobs, 1975; Gordon \& Morel, 1983; Morel \& Prieur, 1977). Thus, the spectral character of natural light leaving the ocean depends largely on $b_{\mathrm{b}}(\lambda) / a(\lambda)$, which in turn depends on the types and concentrations of various constituents present in the water. In order to deduce from ocean color what substances are present in water, and in what concentrations, it is imperative to understand how different constituents of water contribute to absorption and backscattering of light.

By reviewing relevant literature we here discuss the above question pertaining to backscattering. Although we have cited over 180 references to connect the reader with the large body of literature, we admit that this kind of review inescapably must have omitted from consideration other valuable publications on the subject of interest. Our primary motivation was to attempt to write a concise review with a single underlying theme focused on the role of the various seawater constituents in light backscattering. We feel that such a review is timely for a few main reasons. First, the significance of the subject of light backscattering in the ocean has grown considerably over the past years because its scientific implications and practical applications in oceanography are wide ranging, especially in optical remote sensing and two-flow analysis of underwater light fields. Second, uniform description that speaks to the problem has been lacking in all the available texts. And finally, the complexity of natural seawater as an optical medium often obscures the measured optical signals to the point that our present-day interpretation and detailed understanding of major sources of light backscattering and its variability in the ocean are uncertain and controversial.

\section{General considerations on light backscattering in the ocean}

\subsection{Sources of backscattering}

The inhomogeneities of seawater, which are produced by the various molecules, ions, suspended particles, and gas bubbles, are responsible for light scattering in the ocean. The main categories of constituents of natural seawater that determine the inherent optical properties are depicted in Fig. 1. These categories include pure seawater, dissolved organic matter, the various kinds of suspended particles, and gas bubbles (e.g., Mobley, 1994). These constituents cover a broad size range that spans many orders of magnitude from molecular size of the order of $0.1 \mathrm{~nm}$ to large particles or air bubbles that may exceed $1 \mathrm{~mm}$ in size. As will be discussed below, a detailed composition of suspended particulate matter in water is especially important for understanding the sources and variability of light scattering in the ocean.

The molecular scattering of light by pure water or pure seawater, which is free of suspended particles, bubbles, and dissolved organic matter, can be calculated theoretically (see Morel, 1974; Shifrin, 1988). These calculations are based on classical electrodynamics and thermodynamics considerations, in which light scattering is produced by local fluctuations in the density (concentration) of water molecules (Einstein, 1910; Smoluchowski, 1908). Scattering due to fluctuations in orientation of water molecules is added to account for the anisotropy of the molecules (Cabannes, 1929). We note that pure water is here defined as a chemically pure substance that consists primarily of the main isotope of water molecules $\left(\mathrm{H}_{2}{ }^{16} \mathrm{O}\right)$ and smaller amounts of other water isotopes with different molecular weights. Pure seawater has inorganic salts (such as $\mathrm{NaCl}, \mathrm{KCl}, \mathrm{MgCl}_{2}, \mathrm{MgSO}_{4}$, and $\mathrm{CaSO}_{4}$ ) and gases (such as nitrogen, oxygen, argon, and carbon dioxide) dissolved in it. While the dissolved gases have no direct effect on light scattering, the inorganic salts are important (e.g., Shifrin, 1988). Because the dielectric constant and dissociation capacity of water are high, salt molecules are found in the form of ions, the most important of which are $\mathrm{Cl}^{-}, \mathrm{Na}^{+}, \mathrm{SO}_{4}{ }^{2-}$, $\mathrm{Mg}^{2+}, \mathrm{Ca}^{2+}$, and $\mathrm{K}^{+}$. The relative composition of inorganic salts varies weakly in the ocean, so it has been commonly accepted to use a model of pure seawater that consists of two components, pure water and dissolved inorganic salts whose variable concentration is described in terms of salinity. The scattering of light by pure seawater is produced by random fluctuations in the density of water molecules and the various ions 


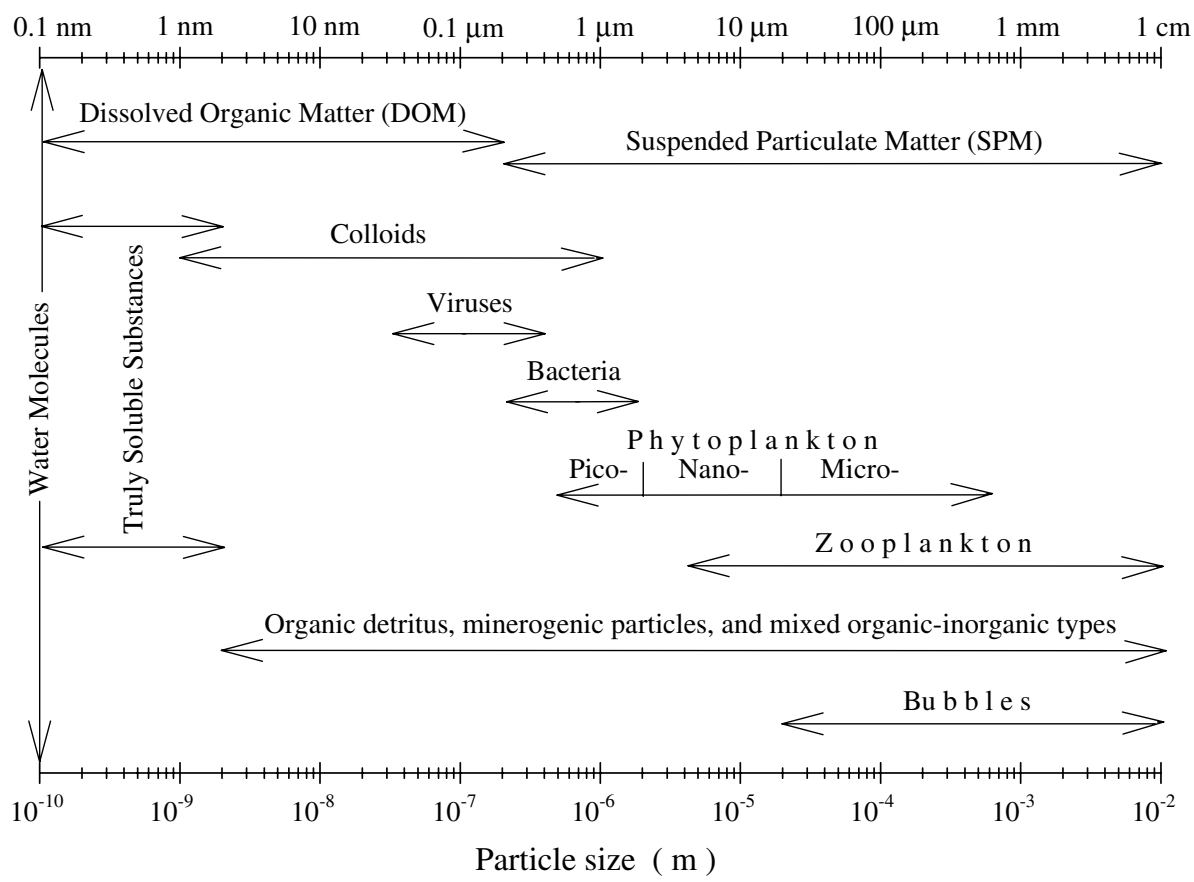

Fig. 1. Schematic diagram showing various seawater constituents in the broad size range from molecular size of the order of $10^{-10} \mathrm{~m}$ to large particles and bubbles of the order of $10^{-3}-10^{-2} \mathrm{~m}$ in size. The arrow ends generally indicate approximate rather than sharp boundaries for different constituent categories.

of salts, so it depends on temperature, pressure, and salinity. Although some experimental data corroborate the theoretical estimates of molecular scattering by water (Morel, 1974), a complete experimental validation remains to be an open challenge. One major difficulty is the preparation of truly pure water; however, building and calibrating appropriate instrumentation for accurate measurements of relatively weak molecular scattering is not trivial either.

The greatest challenge for our understanding of light backscattering in the ocean is, however, related to highly variable contributions associated with all kinds of particles suspended in water. There is a great diversity of particles that may be significant to backscattering (see Fig. 1). The particulate matter includes a variety of living biological cells (viruses, bacteria, numerous phytoplankton and zooplankton species) and non-living particulate matter that is also very heterogeneous in its nature and particle size. The non-living particulate matter includes organic detritus (many kinds of biogenous products and debris), inorganic particles (clay minerals, feldspars, quartz, calcite, and many other mineral species) as well as the mixed organic-inorganic types. Different types of marine particles differ markedly in size, shape, internal structure, and refractive index, which all influence the amount of light scattered by the particles (e.g., Bohren \& Huffman, 1983; Mishchenko, Hovenier, \& Travis, 2000; van de Hulst, 1957). For example, the size of optically significant particles in the ocean can range from the smallest submicrometer colloids to relatively large plankton cells or sand grains that are hundreds of micrometers in size. Air bubbles can also represent a significant and highly variable source of light backscattering in the ocean.

We note that Fig. 1 also shows two general categories of seawater constituents that are broadly defined as dissolved organic matter (DOM) and suspended particulate matter (SPM). In many oceanographic applications, these categories are operationally defined based on filtration of seawater with a certain type of filter. DOM includes the matter contained in seawater, which passes through a small pore size filter, 
typically a polycarbonate membrane filter with a $0.2 \mu \mathrm{m}$ pore size. For determinations of mass concentration of suspended particles in seawater, SPM is defined as the material collected on the $0.2 \mu \mathrm{m}$ pore size filter or, more commonly, on the GF/F glass fiber filter (this type of filter has no actual pore size but it efficiently retains particles larger than about $0.4 \mu \mathrm{m}$ in size). Since early research in optical oceanography (see Jerlov, 1976), the traditional description of total absorption coefficient of seawater, $a(\lambda)$, and total backscattering coefficient of seawater, $b_{\mathrm{b}}(\lambda)$, (or total scattering coefficient $b(\lambda)$ that includes both forward and backward scattering) in terms of additive contributions of constituents has been based on these broadly defined dissolved and particulate components:

$$
\begin{aligned}
& a(\lambda)=a_{\mathrm{w}}(\lambda)+a_{\text {DOM }}(\lambda)+a_{\mathrm{p}}(\lambda), \\
& b_{\mathrm{b}}(\lambda)=b_{\mathrm{bw}}(\lambda)+b_{\mathrm{bp}}(\lambda),
\end{aligned}
$$

where $a_{\mathrm{w}}(\lambda)$ is the absorption coefficient of pure seawater, $a_{\mathrm{DOM}}(\lambda)$ the absorption coefficient of DOM, $a_{\mathrm{p}}(\lambda)$ the absorption coefficient of suspended particles, $b_{\mathrm{bw}}(\lambda)$ the backscattering coefficient of pure seawater, and $b_{\mathrm{bp}}(\lambda)$ the backscattering coefficient of particles.

We recall this common representation of absorption and scattering properties for two main reasons. First, it involves some mismatch between the particulate assemblages contributing to $a_{\mathrm{p}}(\lambda)$ and $b_{\mathrm{bp}}(\lambda)$. In field experiments at sea, $a_{\mathrm{p}}(\lambda)$ is typically measured on particles collected on the GF/F filter and $b_{\mathrm{bp}}(\lambda)$ is determined from measurements on unfiltered seawater. While $b_{\mathrm{bp}}(\lambda)$ includes the contribution of all colloidal particles, $a_{\mathrm{p}}(\lambda)$ excludes small colloids that pass through the GF/F filter. Small colloidal particles are actually included in $a_{\mathrm{DOM}}(\lambda)$. Note also that the mass concentration of particulate matter defined operationally as SPM excludes small colloids, which has ramifications for the interpretation of backscattering measurements in terms of SPM.

Second, and most importantly, in Eqs. (2) and (3) all kinds of suspended particles with different origin, sizes, shapes, internal composition, and optical properties are pooled together into a single particulate component. Although in recent optical analyses and models the particulate component has been often divided into phytoplankton and non-algal particles, such a two-component description is still by far insufficient for explaining and understanding the substantial optical variability in the ocean. This variability is caused by the complex composition of particulate matter accompanied by variations in relative proportions of concentration of different types of particles, each of which has different optical properties. Thus, future advances in our understanding of optical variability will have to rely on a reductionist approach for the optical description of seawater composition. In the reductionist approach, more than just a few broadly defined particulate components must be quantified. Simple expressions such as Eq. (3) for the backscattering coefficient will have to be replaced by

$$
b_{\mathrm{b}}(\lambda)=b_{\mathrm{bw}}(\lambda)+\sum_{i=1}^{N}\left[b_{\mathrm{bp}}(\lambda)\right]_{i},
$$

where $\left[b_{\mathrm{bp}}(\lambda)\right]_{i}$ is the backscattering coefficient of the $i$ th particulate component, which is defined as

$$
\left[b_{\mathrm{bp}}(\lambda)\right]_{i}=N_{i} \times\left[\sigma_{\mathrm{bp}}(\lambda)\right]_{i} .
$$

$N_{i}$ is the number concentration [in $\mathrm{m}^{-3}$ ] of particles belonging to the $i$ th component, and $\left[\sigma_{\mathrm{bp}}(\lambda)\right]_{i}$ is the backscattering cross-section [in $\mathrm{m}^{2}$ ] of a single particle belonging to the $i$ th component. The backscattering cross-section is the product of the geometric cross-section of the particle and the dimensionless efficiency factor for backscattering of the particle, where the efficiency factor is the ratio of radiant power backscattered by the particle to radiant power intercepted by the geometric cross-section of the particle (e.g., Morel $\&$ Bricaud, 1986). For homogeneous spherical particles, the efficiency factor depends only on the complex refractive index of the particle and the particle size relative to light wavelength (e.g., Bohren \& Huffman, 1983). In the general case of irregular and internally heterogeneous particles, the efficiency factor addition- 
ally depends on the particle shape and intraparticle distribution of the complex refractive index (e.g., Mishchenko et al., 2000).

In this reductionist description, we assume that the ith particulate component can be defined in such a way that it is reasonable to use the same backscattering cross-section for all particles belonging to that component. We also note that in Eq. (5), $N_{i}$ can be replaced with the particle mass concentration of the $i$ th component, and accordingly, $\left[\sigma_{\mathrm{bp}}(\lambda)\right]_{i}$ with the mass-specific backscattering coefficient of the $i$ th component. For pigment-bearing phytoplankton components, chlorophyll $a$ concentration and chlorophyll-specific backscattering coefficient of the $i$ th component can be used instead of $N_{i}$ and $\left[\sigma_{\mathrm{bp}}(\lambda)\right]_{i}$.

It is beyond the scope of this paper to discuss further details of potential development of the reductionist approach in the description of optically significant composition of seawater. It suffice to note that for practical reasons such a reductionist approach will have to be based on a manageable number of appropriately defined particulate components rather than every particle species present in water. The criteria for defining particulate components should ensure that the variability in the optical properties between the individual particles belonging to a given component is very much constrained and that all the individual particles of that component play similar and well-defined roles in marine ecosystems and biogeochemistry. Particles of similar origin/function from a restricted range of size may represent a good component in that sense. A tentative list of example components includes viruses, heterotrophic bacteria, picophytoplankton, nanophytoplankton (possibly divided into separate groups of smaller and larger cells), microphytoplankton, microzooplankton, nonliving particles in the colloidal size range, and larger non-living (separately biogenic and minerogenic) particles (see Fig. 1). Some taxonomic groups of plankton with unique optical properties and pigment composition (for example, coccolithophores) may require consideration as a separate component. Here in reviewing the role of different types of particles in light backscattering, we attempt to go beyond the traditional description of particulate matter in terms of just phytoplankton and non-algal particles. However, the level of detail of this review remains naturally still quite limited as imposed by the present knowledge available on backscattering properties of various marine particles and our limited ability to obtain routinely their concentrations in ocean waters.

\subsection{Limitations of theoretical modeling}

The determinations of the backscattering coefficient of seawater containing particles can be based on theoretical modeling, measurements, or approaches that combine both measurements and modeling. Rigorous theoretical computations of backscattering by marine particles are impossible because a complete knowledge of the distributions of particle size, shape, and refractive index (including internal inhomogeneities) is never available to us. Therefore, such computations are normally done under simplifying assumptions. For example, marine particles have been often modeled using the Mie scattering theory (Mie, 1908; see also Bohren \& Huffman, 1983; van de Hulst, 1957) assuming that the particles are homogeneous spheres with a given refractive index and size distribution (e.g., Gordon, 1974; Kullenberg, 1974; Morel, 1973). This approach is useful, especially for certain types of particles or as a guide for the study of particle scattering. However, the Mie theory for homogeneous spheres cannot predict precisely the scattering features from irregularly shaped or inhomogeneous particles (Mishchenko et al., 2000).

Although the light scattered in forward directions by a polydisperse system of irregular particles in random orientations can be similar to that scattered by spheres having the same size distribution (in terms of sphere-equivalent projected area or volume), the differences can be significant for backward scattering angles (e.g., Hodkinson, 1963; Holland \& Gagne, 1970; Mugnai \& Wiscombe, 1989; Schuerman, Wang, Gustafson, \& Schaefer, 1981). Light scattering, including both forward and backward directions, is also sensitive to internal structure of particles (e.g., Kerker et al., 1979; Kitchen \& Zaneveld, 1992; Meyer, 1979; Zaneveld \& Kitchen, 1995; Zieliński, Król, \& Gędziorowska, 1987). The scattering computations for inhomogeneous or nonspherical particles have been made for only a few concrete types of marine 
particles (Gordon \& Du, 2001; Zieliński, Król, Gędziorowska, \& Woliński, 1986). By computing light scattering on disklike particles that imitate calcareous coccoliths detached from phytoplankton cells Emiliania huxleyi, Gordon and Du (2001) showed the strong dependence of backscattering on particle morphology and concluded that "modeling backscattering from marine particles, with their complex shapes, will be very difficult, if not impossible".

\subsection{Determinations from measurements on natural seawater}

Because of unavoidable limitations of theoretical approaches, the scattering measurements on seawater samples and well-characterized suspensions of marine particles will have to play an essential role in advancing our understanding of light backscattering in the ocean. Making direct measurements of $b_{\mathrm{b}}(\lambda)$ or making measurements of $\beta(\psi, \lambda)$ over the entire range of back directions at multiple wavelengths covering the entire spectral range of interest to ocean optics (from UV to near infrared) is a demanding and difficult task that has not been accomplished yet. The early reports on measurements of $\beta(\psi, \lambda)$ of natural waters date back to 1950s and 1960s (Atkins \& Poole, 1952; Beardsley, 1968; Duntley, 1963; Jerlov, 1961; Kullenberg, 1968; Morel, 1966; Sasaki, Okami, Oshiba, \& Watanabe, 1960; Spilhaus, 1968; Tyler, 1961). Those early and many subsequent measurements of $\beta(\psi, \lambda)$ with both in situ and laboratory instruments (e.g., Jonasz \& Prandtke, 1986; Kullenberg, 1984; Mankovsky \& Haltrin, 2002; Morel, 1973; Petzold, 1972; Voss \& Fry, 1984), were all fragmentary in that one or a few discrete wavebands were measured within the limited angular range extending in back directions to about $170^{\circ}$ at best (but see Lee \& Lewis, 2003; Maffione \& Honey, 1992; Voss \& Smart, 1994). The values for the backscattering coefficient $b_{\mathrm{b}}(\lambda)$ of seawater determined directly from those measurements of $\beta(\psi, \lambda)$ have been seldom reported. The best known determinations are based on the tabulated scattering measurements by Petzold (1972) (see also Mobley, 1994). These measurements were made for a relatively broad spectral band centered at $514 \mathrm{~nm}$ and scattering angles between about $0.1^{\circ}$ and $170^{\circ}$ with an extrapolation to $180^{\circ}$. The backscattering coefficient of seawater, $b_{\mathrm{b}}$, determined by Petzold varied from about $0.0016 \mathrm{~m}^{-1}$ in clear ocean waters off the Bahama Islands $(\sim 30 \%$ higher than the molecular backscattering) to $0.037 \mathrm{~m}^{-1}$ in turbid waters in San Diego Harbor ( $\sim 30$-fold higher than the molecular backscattering). The backscattering ratio $\tilde{b}_{\mathrm{b}}$ varied from about 0.013 in coastal ocean off southern California to 0.044 in clear waters off the Bahama Islands. These data show substantial variability in both the magnitude of $b_{\mathrm{b}}$ and $\tilde{b}_{\mathrm{b}}$, and the relative roles played by molecular and particulate backscattering.

The variability has been also demonstrated by early scattering measurements made by Russian investigators (mostly in 1970s) in different regions of the world's ocean. The review of those measurements by Kopelevich (1983) shows, for example, that the backscattering ratio, $\tilde{b}_{\mathrm{b}}$, in the green spectral region can vary between the values of about 0.006 and 0.1 . The analysis by Kopelevich (1983) also showed a general trend of an increase in $\tilde{b}_{\mathrm{b}}$ with depth, for example the values of $\tilde{b}_{\mathrm{b}}$ in the Indian Ocean were, on average, 0.023 for depths less than $100 \mathrm{~m}$, and 0.037 for depths greater than $100 \mathrm{~m}$. In the surface layers, the lowest values of $\tilde{b}_{\mathrm{b}}(<0.007)$ were observed in biologically productive waters of the Peru upwelling and the highest values $(>0.05)$ in turbid coastal waters off the mouths of the Ganges River. These differences were hypothesized to result from the major role of relatively large biological cells in the upwelling region as opposed to smaller particles discharged by the Ganges River.

The substantial range of variability in the volume scattering function including the backward directions, is also supported by recent measurements obtained with a prototype instrument in Atlantic waters off the New Jersey coast (Lee \& Lewis, 2003). These measurements compared well with co-located single angle backscattering measurements (Boss et al., 2004a). Using the 819 phase functions from these recent measurements off the New Jersey coast along with earlier measurements by Petzold (15 measurements) and Mankovsky (41 measurements) from various regions of the world's ocean, Haltrin et al. (2002) analyzed 
the relationship between the backscattering coefficient, $b_{\mathrm{b}}$, and the total scattering coefficient, $b$, within the green spectral region. They established empirical relationships reflecting covariation between $b_{\mathrm{b}}$ and $b$ over the range of $b$ between 0.002 and $10 \mathrm{~m}^{-1}$, and showed that these relationships can be different for optically different water types. For example, for the two water types proposed, the relationships predict the backscattering ratio $\tilde{b}_{\mathrm{b}}$ of about 0.0055 and 0.012 at the same total scattering $b=2 \mathrm{~m}^{-1}$, which again illustrates potential variability in the backscattering properties of natural waters.

\subsection{Determinations for specific types of marine particles}

The scattering measurements on bulk seawater samples (in situ or in vitro) described above say nothing about the contributions by various types of particles present in water. The angular patterns of scattering (often including the polarization properties) for specific types of particle suspensions, mostly cultures of marine phytoplankton, were measured in numerous laboratory studies (e.g., Fry \& Voss, 1985; QuinbyHunt, Hunt, Lofftus, \& Shapiro, 1989; Witkowski, Król, Zieliński, \& Kuteń, 1998; Volten et al., 1998). These studies confirmed that the homogeneous sphere model is usually inadequate for reproducing the measured scattering patterns of real marine particles. In few studies, the backscattering coefficients were determined from such laboratory measurements of angular scattering patterns (Balch et al., 1999; Balch et al., 2000; Voss, Balch, \& Kilpatrick, 1998). The measurements by Balch and co-workers were, however, obtained with a Dawn instrument (Wyatt Technology Corp.), where the sample was illuminated by linearly polarized laser beam and the scattered light was detected with no polarization analyzer. Such measurements do not strictly represent the volume scattering function $\beta(\psi, \lambda)$. In the most recent study of cultures representing 29 species of marine plankton, Vaillancourt, Brown, Guillard, and Balch (2004) report on backscattering data obtained from measurements at four wavelengths with a fixed angle $\left(\sim 140^{\circ}\right)$ backscattering sensor Hydroscat-6 (HobiLabs, Inc).

The estimates of spectral backscattering for various plankton microorganisms are also available from an approach that combines particle size and optical measurements on particle suspensions in the laboratory with theoretical modeling of scattering by homogeneous spheres (Ahn, Bricaud, \& Morel, 1992; Bricaud \& Morel, 1986; Bricaud, Morel, \& Prieur, 1983; Morel \& Ahn, 1990; Stramski \& Kiefer, 1990; Stramski \& Mobley, 1997). A conceptually similar approach that can lead to determinations of particle backscattering was also developed for the combination of flow cytometric measurements of forward and side scattering on individual particles with Mie theory for homogeneous spheres (Ackleson \& Spinrad, 1988; Green, Sosik, Olson, \& DuRand, 2003).

\subsection{Instrumentation for measuring backscattering}

Recent development of commercial instrumentation holds promise for an increase in the amount of backscattering data to be determined from measurements in the ocean and laboratory. Instruments to measure $b_{\mathrm{b}}$ typically fall into one of two categories. In the first, measurements of $\beta(\psi, \lambda)$ at multiple angles are made and integrated to obtain $b_{\mathrm{b}}$. Examples of these instruments are the General Angle Scattering Meter (GASM, see Balch, Holligan, Ackleson, \& Voss, 1991; Petzold, 1972) and the volume scattering meter developed jointly by the Marine Hydrophysical Institute, Academy of Sciences of the Ukraine and Satlantic, Inc., Halifax, Canada (Lee \& Lewis, 2003; Zhang, Lewis, Lee, Johnson, \& Korotaev, 2002). These instruments use a single detector and light source. The measurement of $\beta(\psi, \lambda)$ is made by varying the scattering angle between the source and detector. This method can provide an accurate measure of $b_{\mathrm{b}}$, without concerns about detector-to-detector variability, but because of the time required to sample (on the order of minutes) the number of samples or depths in a profile, which can be measured is restricted. The benchtop instrument Dawn (Wyatt Technology Corp.) used in discrete (Balch et al., 1999) or flow-through mode (Fargion \& McClain, 2001) and an in-situ instrument ECO-VSF (WetLabs, 
Inc., Zaneveld, Pegau, \& Mueller, 2003) allow more rapid sampling by use of multiple detectors at different scattering angles; however detector-to-detector stability must be monitored. It has long been recognized that accurate absolute measurements of $\beta(\psi)$ impose stringent requirements on the design and calibration of the instruments (Fry, 1974; Jonasz, 1990; Kratohvil, Dezelic, Kerker, \& Matijevic, 1962; Kullenberg, 1968; Lee \& Lewis, 2003; Maffione \& Dana, 1997; Pritchard \& Elliot, 1960; Tyler \& Richardson, 1958). Some of the issues that hold the key to accurate measurements involve radiometric calibration, angle and scattering volume calibrations, sensor-response function and optical geometry (involving the scattering volume, illumination beam, detection of scattered light, and path length in the water), proper angular resolution, temperature and pressure effects, as well as optical and mechanical imperfections of the instrument.

Several efforts have been made to find an angle, $\psi_{0}$, in the backscattering direction for which the ratio of $\beta\left(\psi_{0}, \lambda\right) / b_{\mathrm{b}}$ is nearly constant (Boss \& Pegau, 2001; Maffione \& Dana, 1997; Oishi, 1990). Instruments such as the Hydroscat- 6 with a centroid angle near $140^{\circ}$ (HobiLabs, Inc.) use this principle to determine $b_{\mathrm{b}}$ from the measurement of $\beta\left(\psi_{0}, \lambda\right)$. These instruments are relatively simple, easy to use, and provide rapid measurements, but depend on this approximation. These instruments have no enclosure for the scattering volume, which avoids restrictions and modifications of the sample, but still require careful and proper calibration to achieve absolute measurements (Maffione \& Dana, 1997). Using recent measurements made off the New Jersey coast, Boss and Pegau (2001) showed that the good relationship between $\beta\left(\psi_{0}, \lambda\right)$ and $b_{\mathrm{b}}$ for $\psi_{0}$ near $120^{\circ}$ could be explained by variable contribution of molecular scattering by water and that once pure water contribution is removed, all angles from 110 to $150^{\circ}$ are adequate to estimate the backscattering coefficient (the estimated error is smaller than 10\%).

\section{The roles of various seawater constituents in light backscattering}

\subsection{Pure water}

The main features of the molecular scattering by water are (Morel, 1974; Shifrin, 1988): (i) scattering is anomalously weak compared to other liquids because of the relatively small isothermal compressibility and refractive index for the closely packed molecular structure of water; (ii) the scattering coefficient by pure seawater (salinity $35-39 \%$ ) is about 30\% greater at visible wavelengths than that for pure deionized water; (iii) the angular distribution of scattering has maxima in the forward $(\psi=0)$ and backward $(\psi=\pi)$ directions and minima in the side directions $(\psi=\pi / 2)$; (iv) as molecules tend to scatter light equally in the forward and backward directions, the molecular backscattering coefficient, $b_{\mathrm{bw}}(\lambda)$, is half of the total molecular scattering coefficient, $b_{\mathrm{w}}(\lambda)$, and the backscattering ratio $\tilde{b}_{\mathrm{bw}}(\lambda)=0.5$; and $(\mathrm{v}) b_{\mathrm{w}}(\lambda)$ and $b_{\mathrm{bw}}(\lambda)$ of pure seawater show the wavelength dependence of $\lambda^{-4.32}$.

The molecular scattering of water is usually considered to be known and constant. The variability between pure fresh water and pure saline seawater associated with variable salinity must be taken into account but relatively small variations due to changes in water temperature and pressure can be ignored for most scattering-related applications. Morel (1974) and Smith and Baker (1981) tabulated the values of molecular scattering of water, which are in common use today in oceanography. For pure seawater (salinity 35-39\%), the values of $b_{\mathrm{bw}}(\lambda)$ decrease from about $0.0038 \mathrm{~m}^{-1}$ at $400 \mathrm{~nm}$ to $0.00035 \mathrm{~m}^{-1}$ at $700 \mathrm{~nm}$. More recently, Buiteveld, Hakvoort, and Donze (1994) recalculated the scattering coefficients for pure fresh water using different inputs (including temperature effect) to the Einstein-Smoluchowski equation of the fluctuation theory than those earlier employed by Morel (1974). The values of the scattering coefficient of Buiteveld et al. (1994) are somewhat lower that those of Morel at wavelengths shorter than $680 \mathrm{~nm}$ and somewhat higher above $680 \mathrm{~nm}$. However, Buiteveld et al. (1994) did not examine the effect of salinity, and the Morel or Smith and Baker coefficients continue to be used in oceanography as 'standard' values for pure seawater. 
The strong effect of salinity on molecular scattering is especially important in coastal areas where large gradients in salinity associated with fresh water inputs occur.

While the contribution of water molecules to the total scattering coefficient of seawater is typically small $(<10 \%)$ or negligible $(<1 \%)$, this is not the case for the backscattering coefficient. For ocean waters with relatively low concentrations of particles and bubbles, $b_{\mathrm{bw}}(\lambda)$ is on the order of tens of percent of the total backscattering coefficient of seawater, $b_{\mathrm{b}}(\lambda)$. In clearest natural waters, this contribution can exceed $50 \%$ and reach even $80 \%$ in the blue spectral region (Boss, Collier, Larson, Fennel, \& Pegau, 2004; Morel \& Gentili, 1991).

\subsection{Turbulence}

Turbulent fluctuations of passive scalars in water such as temperature and salinity cause fluctuations in the density of fluid, and hence in the refractive index of water. Most oceanic flows are turbulent and are characterized by a wide range of coexisting scales of motion. For example, temperature within an oceanic eddy varies on scales ranging typically from $\mathrm{O}(10) \mathrm{m}$ down to $\mathrm{O}(1) \mathrm{mm}$ (i.e., from the order of $10 \mathrm{~m}$ down to the order of $1 \mathrm{~mm}$, see Ozmidov, 1965). The turbulence-induced inhomogeneities of refractive index are responsible for forward scattering of light, which has long been recognized in the ocean optics literature (Bogucki, Domaradzki, Stramski, \& Zaneveld, 1998; Chilton, Jones, \& Talley, 1969; Hodara, 1973; Honey \& Sorensen, 1970; Kopilevich, Aleksejev, Kurasov, \& Yakovlev, 1994; Wells, 1973).

The refractive index inhomogeneities are frequently caused by the temperature field. The relative contribution of different spatial scales to the light scattering depends on the temperature variance spectrum $C_{n} E_{\mathrm{T}}(k)$, i.e. the three-dimensional spectrum of temperature fluctuations in the Fourier sense, where the wave number $k$ is inversely proportional to the length scale of inhomogeneity, the parameter $C_{n}$ is proportional to the mean square temperature variance, and $E_{\mathrm{T}}(k)$ describes how much of the total variance comes from the wavenumbers (spatial scales) between $k$ and $k+\mathrm{d} k$. The spectrum $C_{n} E_{\mathrm{T}}(k)$ is universal (Batchelor, 1959) and depends on the mean temperature gradient in the water, the rate of dissipation of turbulent kinetic energy $\varepsilon$, and the temperature variance dissipation rate $\chi$ (Bogucki, Domaradzki, \& Yeung, 1997). The direct dependence on $\chi$ and $\varepsilon$ is included in $C_{n}$. The optical properties of a homogeneous and isotropic turbulent flow can be characterized by $\chi$ which expresses the strength of the small scale temperature gradient, and $\epsilon$ which is inversely proportional to the size of the smallest flow structures. Typically, $\chi$ ranges from $10^{-2} \mathrm{deg}^{2} \mathrm{~s}^{-1}$ just below the ocean surface to $10^{-10} \mathrm{deg}^{2} \mathrm{~s}^{-1}$ at mid-water column. The range of $\varepsilon$ is from $10^{-4} \mathrm{~m}^{2} \mathrm{~s}^{-3}$ in turbulent surface layers to $10^{-10} \mathrm{~m}^{2} \mathrm{~s}^{-3}$ in the mid-water column (Dillon, 1984).

The measurements of $\beta(\psi)$ made in the ocean by Petzold (1972) appear to support a conjecture that turbulence may be a dominant source of light scattering at very small forward scattering angles. The measured scattering functions exhibit a significant increase with decreasing scattering angle at small angles $\left(\psi<1^{\circ}\right)$. This behavior is apparently caused by turbulence as it is not consistent with forward scattering on particles suspended in a non-turbulent medium (Bogucki et al., 1998). However, the effect of turbulence on light backscattering is orders of magnitude weaker compared to the small angle forward scattering, and consequently the backscattering has received little attention. Kopilevich and Feigels (1994) suggested that turbulent layers within the water column can be responsible for anomalous enhancement of the backscatter signal observed in airborne lidar experiments.

We can estimate to the first order the magnitude of backscattering due to turbulence from an analytical formula that relates the volume scattering function $\beta$ at the scattering angle $\psi$ to characteristics of homogeneous isotropic turbulent flow (Tatarski, 1961). This relationship is $\beta(\psi, \lambda)=C_{\mathrm{n}} \sin ^{-2}(\psi / 2) E_{\mathrm{T}}(\psi, \lambda)$, where the parameter $C_{\mathrm{n}}$ depends on local values of $\chi$ and $\varepsilon$, as well as on the wavelength of light $\lambda$. The scattering function $\beta(\psi, \lambda)$ is related to the spectrum of temperature fluctuations $E_{\mathrm{T}}(\psi, \lambda)$, which is strongly peaked in 
forward scattering angles $\psi$. The spectrum $E_{\mathrm{T}}(\psi, \lambda)$ is evaluated at the Fourier component of the fluctuations corresponding to the length scale of the fluctuations equal to $\left[4 \pi \lambda^{-1} \sin (\psi / 2)\right]^{-1}$. Using the light propagation equation (for $\lambda=640 \mathrm{~nm}$ ) in the presence of turbulent flow (Bogucki et al., 1998) and the above dependence of $\beta$ on $\psi$ (Tatarski, 1961), we find that the turbulence-induced backscattering coefficient, $b_{\mathrm{bt}}$, can vary within a broad range. For turbulent flows with $\chi=10^{-7} \mathrm{deg}^{2} \mathrm{~s}^{-1}$ and $\varepsilon=10^{-6} \mathrm{~m}^{2} \mathrm{~s}^{-3}, b_{\mathrm{bt}}$ is only of $\mathrm{O}\left(10^{-9}\right) \mathrm{m}^{-1}$. This estimate is very small as the molecular backscattering by pure seawater is of $\mathrm{O}\left(10^{-4}-10^{-3}\right) \mathrm{m}^{-1}$ in the visible spectral region. The low values of $b_{\mathrm{bt}}$, perhaps up to $\mathrm{O}\left(10^{-7}-10^{-6}\right)$ $\mathrm{m}^{-1}$, are expected to be common in oceanic turbulent flows. However, under particular conditions $b_{\mathrm{bt}}$ can be as high as $10^{-2} \mathrm{~m}^{-1}$ when $\chi=10^{-3} \mathrm{deg}^{2} \mathrm{~s}^{-1}$ and $\varepsilon=10^{-10} \mathrm{~m}^{2} \mathrm{~s}^{-3}$. Such conditions will occur within flows with low rates of dissipation of turbulent kinetic energy in the presence of a large mean temperature gradient, which may perhaps happen at the base of the mixed layer. This is because the magnitude of $b_{\mathrm{bt}}$ is strongly proportional to $\chi$ and only weakly and inversely dependent on $\epsilon$, so we expect the highest values of $b_{\mathrm{bt}}$ for flows with high $\chi$ and low $\epsilon$.

Although turbulent inhomogeneities are unlikely to be a major contributor to backscattered light under most oceanic conditions, further research in this area is needed, especially as the optical measurements have the potential to provide new non-invasive methods to observe turbulent parameters in the ocean. This is an emerging field of study which is still based on incompletely verified theories and few adequate experiments. We note that the theoretical derivations such as those by Tatarski (1961) are based on some key assumptions (notably the Born approximation and a short propagation distance). In addition, no specially designed laboratory measurements of $\beta(\psi)$ in turbulent flows simulating oceanic conditions have been made as yet and the field observations of $\beta(\psi)$ in the past were not accompanied by measurements of turbulence parameters.

\subsection{Bubbles}

Most of the bubbles found near the ocean surface are generated by breaking surface waves but the sources of bubbles also include rainfall, biological processes in living organisms, decomposition of organic matter, and release from the ocean floor (e.g., Medwin \& Clay, 1998). Using a laser holography technique, O'Hern, D'Agostino, and Acosta (1988) suggested that there can be as many as $10^{5}$ to $5 \times 10^{6}$ bubbles of 30 $\mu \mathrm{m}$ in diameter per $\mathrm{m}^{3}$ of ocean water even during calm seas in the absence of breaking waves. By combining Mie scattering calculations for homogeneous spheres with the bubble data for quiescent seas, Stramski (1994) suggested that such conservative estimates of the bubble concentrations indicate small but non-negligible contribution to the total scattering and backscattering coefficients in the upper ocean of $\mathrm{O}(1-10) \%$.

While bubbles are nearly spherical in shape, they can rapidly adsorb surface-active materials onto their surface (Detwiler \& Blanchard, 1978; Thorpe, 1982), which makes the coated sphere an adequate model for optical computations. Zhang, Lewis, and Johnson (1998) performed Mie scattering calculations for both clean bubbles and bubbles coated with an organic film. The coatings were shown to exert a small influence on total scattering by bubbles larger than $10 \mu \mathrm{m}$ in size, but the estimated effect on backscattering was significant (as much as a 4-fold enhancement). The backscattering enhancement presumably associated with the coating on bubbles was also observed experimentally (Zhang et al., 2002).

Because air entrainment by breaking waves is a major mechanism for producing significant bubble concentrations near the sea surface, the light scattering by bubbles at shallow depths is highly variable over a range of time- and space scales. This variability was assessed from Mie scattering calculations for time series of the bubble size distributions (bubble size $>20 \mu \mathrm{m}$ ) measured acoustically in rough conditions (wind speed $U_{10}=15 \mathrm{~m} \mathrm{~s}^{-1}$, significant wave height $H_{1 / 3}=3.2 \mathrm{~m}$ ) (Terrill, Melville, \& Stramski, 2001). This assessment shows that the bubble scattering can span several orders of magnitude over time periods of $\mathrm{O}(1-10) \mathrm{min}$. The effects of bubbles on $b_{\mathrm{b}}$ were shown to be significant at the void fractions above $10^{-6}$, when the bubble backscattering is greater than $10^{-4} \mathrm{~m}^{-1}$ (the void fraction is a volumetric fraction of 
air in water). Inside bubble clouds where void fraction is of $\mathrm{O}\left(10^{-4}\right)$ or more, the bubble-induced $b_{\mathrm{b}}$ exceeds $10^{-2} \mathrm{~m}^{-1}$, which can completely dominate the total backscattering. The significant enhancement of the mean (time-averaged) volume scattering function under high-wind periods compared to low-wind periods was recently observed in the coastal ocean off New Jersey (Zhang et al., 2002).

At present, one important limitation of better understanding of the role of bubbles in light scattering is the lack of information about the possible presence of small-sized bubbles (from $<1$ to $\sim 20 \mu \mathrm{m}$ ) in ocean water. Although relatively large bubbles (generally $>20 \mu \mathrm{m}$ ) were measured in many oceanographic experiments in the past (e.g., Medwin \& Clay, 1998), the available measurement techniques have not yet permitted an unambiguous detection of smaller bubbles in the ocean. If small-sized bubbles are found in sufficient quantities in future studies, especially persistent populations of small bubbles stabilized with surface coating (see Johnson \& Cooke, 1981), such a discovery may indicate an important source of optical backscattering (Zhang et al., 2002).

The enhanced backscattering by bubbles during the events of entrainment by breaking waves has a significant impact on reflectance of the ocean. Radiative transfer simulations show that moderate entrainment events at winds of about $10 \mathrm{~m} \mathrm{~s}^{-1}$ can produce $>2$-fold increase in remote-sensing reflectance, $R_{\mathrm{rs}}$, as observed just above the submerged bubble cloud (Stramski \& Tęgowski, 2001). Although the light scattering by bubble clouds (assuming the absence of small-sized bubbles) is generally flat in the visible range, the spectral effect on ocean reflectance is such that the water patch containing bubbles appear greener or more yellowish than the surrounding waters with no bubbles. We note that breaking waves generate not only underwater bubble clouds but also the foam at the ocean surface (i.e., large bubbles of air separated by a thin layer of water and accumulating at the surface). The foam is strongly scattering with large impact on ocean reflectance (e.g., Frouin, Schwindling, \& Deschamps, 1996; Moore, Voss, \& Gordon, 2000) but these effects are beyond the scope of our discussion.

\subsection{Organic and inorganic particles}

The particulate matter contains both biogenic and minerogenic material whose relative amounts are variable in the ocean. Organic particles include two major categories of particulate matter: living plankton microorganisms (viruses, bacteria, and various phytoplankton and zooplankton species) and non-living organic detritus (breakdown products of microorganisms). Inorganic particles include the various mineral species (clay minerals, quartz, feldspars, calcite and many others). Tens of thousands of species of marine plankton have been identified (e.g., Tomas, 1997) and a few thousand mineral species are known, which include a few dozen of the minerals that are essential constituents of rocks (e.g., Berry, Mason, \& Dietrich, 1983). Many marine particles would probably be best described as mixed organic-inorganic types. Although the mix of organic and inorganic matter may be quite well characterized for some plankton species that produce inorganic 'shells' (e.g., coccolithophores, diatoms), it is generally poorly known for heterogeneous assemblages of non-living particles.

Both the concentration and species composition of organic and inorganic particles vary greatly in the ocean. The particle size distribution in the ocean, which describes the particle concentration as a function of particle size, typically shows a rapid decrease of concentration with increasing size from a submicrometer range to hundreds of micrometers. This feature is common for all the suspended particles and also just for plankton microorganisms (e.g., Jackson et al., 1997; McCave, 1983; Sheldon, Prakash, \& Sutcliffe, 1972; Stramski \& Kiefer, 1991). For example, the concentrations of viruses (particle size generally less than $0.2 \mu \mathrm{m}$ ) in ocean waters can be of $\mathrm{O}\left(10^{6}-10^{8}\right) \mathrm{cm}^{-3}$, heterotrophic bacteria (cell size from about $0.2-1$ $\mu \mathrm{m})$ of $\mathrm{O}\left(10^{5}-10^{6}\right) \mathrm{cm}^{-3}$, and the smallest photosynthetic phytoplankton (the cell size from about 0.5 to about $1 \mu \mathrm{m}$ ) as high as $\mathrm{O}\left(10^{4}-10^{5}\right) \mathrm{cm}^{-3}$ (e.g., Li, 1995; Maranger \& Bird, 1995). The concentration of non-living particles in the submicrometer size range can be a few orders of magnitude higher than that 
of the smallest marine microbes (Koike, Hara, Terauchi, \& Kogure, 1990). As the particle size increases above $1 \mu \mathrm{m}$, the concentration of particles usually continues to decrease rapidly. The information about particle concentrations and sizes is very important to optical analysis. Both the concentration of a given type of particle in water and the optical properties of individual particles of that type (which depend, among other things, on particle size) determine the role of these particles in the bulk ocean optical properties (e.g., Morel \& Ahn, 1991; Stramski \& Kiefer, 1991).

The index of refraction can be a useful parameter describing the origin of particles, which is also an important determinant of the optical properties. The living plankton cells consist of soft watery protoplasm that result in low refractive index relative to water $(<1.1$, typically around $1.04-1.05)$. The inorganic material, including hard skeletal or shell material produced by organisms, has high refractive index of about 1.15 or higher (Aas, 1996; Zaneveld, Roach, \& Pak, 1974). Zaneveld et al. (1974) suggested a bimodal distribution of phytoplankton refractive index with most cellular material (watery protoplasm) having an index of refraction between 1.02 and 1.05 and a smaller fraction of the material having an index around 1.15.

A number of early studies of light scattering in the ocean have dealt with the question of what types of particles dominate the scattering (e.g., Brown \& Gordon, 1974; Kullenberg, 1974; Morel, 1973; Zaneveld et al., 1974). Typically, these studies searched for the values of refractive index of particles, which best reproduce observed scattering measurements, given an observed or postulated particle size distribution. Different, sometimes highly contrasting results for the same oceanic region, were obtained. The particulate models consisting of one component characterized by low refractive index (Morel, 1973) or high refractive index (Kullenberg, 1974) as well as the models with more than one component including both low- and high-index particles (Brown \& Gordon, 1973; Brown \& Gordon, 1974; Zaneveld et al., 1974) were proposed to explain the observed light scattering. Despite intrinsic limitations (due to, for example, unknown particle size distribution in the submicrometer range, inadequacies of scattering calculations with a homogeneous sphere model, or multiple scattering solutions corresponding to different particle size-refractive index distributions), these early analyses provided important suggestions such as high-index minerals (in small and/ or mid size fractions) produce much or most of the scattering, especially at large angles, and that the large quantities of submicrometer (presumably organic) particles can be a significant source of backscattering (Brown \& Gordon, 1974; Gordon, 1974).

More recently, it was suggested that in typical non-bloom open ocean waters, phytoplankton or all the microorganisms account for a relatively small fraction of particulate backscattering, and that most of the backscattering may be due to non-living particles, mainly from the submicron size range (Morel \& Ahn, 1991; Stramski \& Kiefer, 1991). The potential role of small-sized organic detritus as a major source of backscattering was emphasized but the significance of minerals was not excluded (see also Stramski, Bricaud, \& Morel, 2001). Among microorganisms, heterotrophic bacteria can be most important, especially when their concentrations are close to or exceed $10^{12}$ cells per $\mathrm{m}^{3}$. Viruses at their typical oceanic concentrations were estimated to be insignificant. The optical impact of coccolithophorid phytoplankton (coccolithophores) can be, however, very important (Balch, Kilpatrick, Holligan, Harbour, \& Fernandez, 1996). These phytoplankton species produce calcite scales called coccoliths that are characterized by a high refractive index. It was estimated that even outside the coccolithophore bloom, 5-30\% of the total backscattering could be associated with coccoliths (calcite plates detached from cells) and plated cells. It has become clear that to successfully explain the backscattering by marine particles, a thorough quantitative characterization of the diverse types of particles present in seawater and their backscattering properties is needed.

\subsubsection{Microorganisms}

Stramski et al. (2001) assembled optical data including the spectral backscattering for viruses, heterotrophic bacteria, and 16 phytoplankton species. The data are based on an approach that combines the optical and particle size measurements made on cultures of microorganisms with the Mie scattering calculations for homogeneous spheres. In this approach, the optical measurements included the spectral beam attenu- 
ation coefficient of particles, $c_{\mathrm{p}}(\lambda)$, spectral absorption coefficient of particles, $a_{\mathrm{p}}(\lambda)$, and possibly also some relative measure of the portion of the backscattering coefficient (see Ahn et al., 1992). While the determinations of beam attenuation, absorption, and total scattering properties from that approach were straightforward and subject only to experimental uncertainties, the determinations of backscattering were more complicated. In the experiments with no backscattering measurements, the measured $c_{\mathrm{p}}(\lambda), a_{\mathrm{p}}(\lambda)$, and particle size distributions were first used to estimate the real and imaginary parts of the refractive index of particles from an inverse optical model for homogeneous spheres, and then the estimated refractive index and the measured size distribution were used in Mie calculations to provide the scattering phase functions and the backscattering ratio (Bricaud \& Morel, 1986; Stramski \& Mobley, 1997). The product of the estimated backscattering ratio, $\tilde{b}_{\mathrm{bp}}(\lambda)$, and the measured scattering coefficient, $b_{\mathrm{p}}(\lambda)=c_{\mathrm{p}}(\lambda)-a_{\mathrm{p}}(\lambda)$, provided the spectral backscattering coefficient of particles, $b_{\mathrm{bp}}(\lambda)$. In the experiments by Ahn et al. (1992), the Mie calculations of the scattering function were used to convert the fraction of backscattering that was measured (less than $20 \%$ of the backscattering coefficient) into the absolute values of $b_{\mathrm{bp}}(\lambda)$.

In the data set assembled in Stramski et al. (2001), the backscattering cross-section of single planktonic particles (i.e., the backscattering coefficient of particles in suspension divided by the number concentration of particles in suspension) spans 6-7 orders of magnitude at visible wavelengths with the lowest values of $\mathrm{O}\left(10^{-7}-10^{-6}\right) \mu \mathrm{m}^{2}$ per particle for viruses (an average particle size $\sim 0.07 \mu \mathrm{m}$ ) and the highest values of $\mathrm{O}(1)$ $\mu \mathrm{m}^{2}$ per particle for the microphytoplankton cells of Prorocentrum micans $(\sim 30 \mu \mathrm{m}$ in size). The spectral shapes of backscattering also differ significantly between the different microorganisms. The backscattering of viruses increases with decreasing light wavelength, there is little spectral dependence for heterotrophic bacteria, and the various phytoplankton species exhibit different spectral shapes with more or less pronounced features within the major absorption bands of pigments. The backscattering ratio $\tilde{b}_{\mathrm{b}}(\lambda)$ remains below $10^{-2}$ for all plankton species in that data set with the exception of viruses. Viruses have high backscattering ratios $(\sim 0.4$ at visible wavelengths) because their size is much smaller than the wavelength of light. For most phytoplankton species, the backscattering ratio is of $\mathrm{O}\left(10^{-3}\right)$. The plated cells of coccolithophorid phytoplankton may have a higher backscattering ratio as the backscattering by such cells is significantly higher than that for naked cells of the same species (Voss et al., 1998).

The backscattering data presented in Stramski et al. (2001) are subject to uncertainty, especially due to the scattering calculations for homogeneous spheres. In reality, plankton cells generally consist of some kind of cell 'wall' and the inner part that is structured in form of organelles, which have different and variable optical properties. The calculations for the layered (coated) spheres that simulate biological cells show enhanced backscattering compared with homogeneous spheres by as much as one order of magnitude (Kitchen \& Zaneveld, 1992; Meyer, 1979; Zaneveld \& Kitchen, 1995). The layered sphere models are still not necessarily accurate in quantifying backscattering by real biological cells due to assumptions about the thickness of cell wall and overly simplified representation of cell shape and internal cell structure. By measuring the volume scattering function on several phytoplankton cultures, Volten et al. (1998) showed that Mie calculations for homogeneous spheres produce steeper scattering functions (relatively less backscattering) than the functions measured in the angular range between $20^{\circ}$ and $160^{\circ}$. Stramski and Piskozub (2003) showed that three-dimensional radiative transfer simulations of the scattering error in measurements of phytoplankton absorption suggest that the backscattering ratios $\tilde{b}_{\mathrm{bp}}(\lambda)$ can be as much as 10 times higher for Thalassiosira pseudonana (a marine diatom $4 \mu \mathrm{m}$ in size) and three times higher for a cyanobacterium Synechococcus $(1 \mu \mathrm{m}$ in size) than the estimates from the Stramski et al. (2001) data set.

In the most recent study, Vaillancourt et al. (2004) determined the backscattering properties at four wavelengths for marine heterotrophic bacteria and 28 phytoplankton species from laboratory measurements on cultures with the Hydroscat-6 instrument. This work also showed that phytoplankton backscattering is higher than that estimated from the approaches involving Mie calculations for homogeneous spheres. Vaillancourt et al. indicated that their median value for phytoplankton backscattering efficiency 
at $510 \mathrm{~nm}, Q_{\mathrm{bb}}(510)$, based on 28 phytoplankton species is 10 -fold higher than a median value of $Q_{\mathrm{bb}}(510)$ based on 16 phytoplankton species from the Stramski et al. (2001) data set. We note that the values of backscattering efficiency, $Q_{\mathrm{bb}}(\lambda)$, and backscattering cross-section, $\sigma_{\mathrm{bb}}(\lambda)$, are related to one another according to: $\sigma_{\mathrm{bb}}(\lambda)=Q_{\mathrm{bb}}(\lambda) \times G$, where $G$ is the projected-area of plankton cells (e.g., Bricaud \& Morel, 1986). The above-mentioned comparison of the median values of $Q_{\mathrm{bb}}(510)$ may be misleading or overstating the differences between the two data sets. There are only three phytoplankton species out of 28 species in the Vaillancourt et al. data set (i.e., Isochrysis galbana, Thalassiosira pseudonana, and Dunaliella tertiolecta), which are also included in the Stramski et al. data set. A comparison for these three species shows that the $Q_{\mathrm{bb}}(510)$ estimates of Vaillancourt et al. are higher than those of Stramski et al. by a factor of 2.7, 4.2, and 6.2 for I. galbana, D. tertiolecta, and T. pseudonana, respectively. Note that these differences are significantly smaller than the factor of 10 reported by Vaillancourt et al. for the median values based on the entire data sets. In addition, the differences between the two data sets depend on wavelength of light. While at blue wavelengths the differences are larger than at $510 \mathrm{~nm}$, the differences at $620 \mathrm{~nm}$ are smaller than those at $510 \mathrm{~nm}$. For example, the Vaillancourt et al. estimates of $Q_{\mathrm{bb}}(620)$ are higher than those of Stramski et al. by a factor of $1.5,2.4$, and 4.2 for D. tertiolecta, I. galbana, and T. pseudonana, respectively. Part of these differences is still perhaps attributable to differences in growth conditions in phytoplankton cultures between the two studies. Nevertheless, the experimental estimates of Vaillancourt et al., although also being subject to uncertainties, further support the conclusion that the Mie calculations result in some underestimation of phytoplankton backscattering. We caution, however, against an assumption that the underestimation for the various phytoplankton species is typically as high as one order of magnitude or higher. Our comparative analysis of limited data for a few species suggests that while the underestimation by a factor of 10 is possible, typical underestimation at most light wavelengths is smaller and ranges from a factor of less than 2-6 or so. Clearly, more work aiming at accurate determinations of spectral backscattering from measurements made on the various plankton species is needed for better quantification of the backscattering properties of marine microorganisms.

\subsubsection{Non-living organic and minerogenic particles}

The quantitative information on the backscattering properties of non-living particles is even more limited than that for microorganisms. Few measurements of the scattering function (within the restricted angular range) were reported for non-living marine particles but the investigated particles were not characterized in terms of size distribution or composition (Sugihara, Kishino, \& Okami, 1982; Volten et al., 1998). Some data from inland waters on the backscattering by particle assemblages dominated by minerals were summarized in Bukata, Jerome, Kondratyev, and Pozdnyakov (1995), but those indirect determinations may involve substantial uncertainty. To our knowledge, no measurements of backscattering of 'well-characterized' organic detritus or mineral particles isolated from ocean waters were made, so the available data come primarily from scattering calculations that involve assumptions about particle properties (size and refractive index distributions). For example, using Mie calculations for homogeneous spheres, Stramski et al. (2001) determined the spectrum of backscattering cross-section of a hypothetical 'average' biogenic detrital particle derived from a broad Junge-type size distribution of particles with a slope of -4 between 0.05 and $500 \mu \mathrm{m}$. The real part of refractive index for these particles was assumed to be 1.04 (relative to water) at all visible wavelengths and the imaginary part of the index was assumed to satisfy the exponential law: $n^{\prime}(\lambda)=0.010658 \mathrm{e}^{-0.007186 \lambda} \lambda$. This exponential function was derived from absorption measurements that were made on individual detrital particles in the Sargasso Sea by Iturriaga and Siegel (1989). We note that there is a typographical error in the equation for $n^{\prime}$ on p. 2935 of the publication by Stramski et al., 2001, and also that their calculations for detritus were made with the $n^{\prime}(\lambda)$ values that are $25 \%$ lower than those predicted by the above exponential function. The backscattering cross-section resulting from those calculations was described by a power function of wavelength: $\sigma_{\mathrm{bb}}(\lambda)=5.88 \times 10^{-4} \lambda^{-0.9}$ (where $\sigma_{\mathrm{bb}}$ is in $\mu \mathrm{m}^{2}$ per particle and $\lambda$ is in $\mathrm{nm}$ ). 
By using the value of 1.18 instead of 1.04 for the real refractive index and keeping all other assumptions unchanged, similar calculations were made by Stramski et al. (2001) to obtain the spectral backscattering cross-section of a hypothetical 'average' mineral particle derived from a broad Junge-type size distribution. The result was: $\sigma_{\mathrm{bb}}(\lambda)=1.79 \times 10^{-2} \lambda^{-0.91}$, which predicts, as expected, much stronger backscattering for the high-index particles (minerals) compared to the low-index particles (watery organics). In these calculations, the 'average' mineral particle backscatters 30-times more than the 'average' soft organic particle. These theoretical estimates have, however, limited significance and must be used with caution as they are valid only for spherical homogeneous particles with the assumed refractive index and the broad Junge size distribution with a single slope of -4 . The real detrital and mineral particles in the ocean do not satisfy these assumptions and we must await further research to be able to better quantify the actual magnitudes and variability in the spectral backscattering properties of these particles.

\subsection{Colloids}

It is important to develop an understanding of the roles played not only by different types of particles but also by different particle size fractions in light backscattering in the ocean. Colloidal particles from the submicrometer size range are of particular interest because they were suggested to be a major source of particulate backscattering (Brown \& Gordon, 1974; Morel \& Ahn, 1991; Stramski \& Kiefer, 1991; Ulloa, Sathyendranath, \& Platt, 1994). Colloids lie at the boundary between truly soluble chemical species and sinking particles, and are generally defined as tiny particles, macromolecules, and molecular assemblies in the size range between about $1 \mathrm{~nm}$ and $1 \mu \mathrm{m}$ (Vold \& Vold, 1983; Buffle \& van Leeuwen, 1992). Colloidal particles in this size range are small enough for gravitational settling to be insignificant but large enough to possess an interface and interior, which are chemically distinct from the surrounding medium. Colloidal phase consists of a great variety of polymeric organic substances and gels (which include polysaccharides, proteins, peptides, fulvic and humic acids, and cellular debris), inorganic particles (such as oxides and hydroxides of $\mathrm{Al}, \mathrm{Fe}, \mathrm{Mn}$ and $\mathrm{Si}, \mathrm{Ca}$ and $\mathrm{Ca}-\mathrm{Mg}$ carbonates, and clay minerals), organic-inorganic complexes, as well as living microbes (heterotrophic and phototrophic bacteria) and viruses (e.g., Chin, Orellana, \& Verdugo, 1998; Leppard, West, Flanningan, Carson, \& Lott, 1997; Santschi, Balnois, Wilkinson, Zhang, \& Buffle, 1998; Wells \& Goldberg, 1994).

Colloids are the most abundant particles in the ocean. The number concentrations of small colloids (sized between about 5 and $200 \mathrm{~nm}$ ) can exceed $10^{9} \mathrm{~cm}^{-3}$ (Wells \& Goldberg, 1991, 1994), which is at least one order of magnitude higher than typical concentrations of viruses that fall into that size range (Bergh, Børsheim, Bratbak, \& Heldal, 1989; Maranger \& Bird, 1995). The abundance of larger colloids (0.4-1 $\mu \mathrm{m}$ in size) can reach $10^{7} \mathrm{~cm}^{-3}$, which is typically $1-2$ orders of magnitude higher than the number of bacteria within that submicron range (Koike et al., 1990; Yamasaki et al., 1998). These results indicate the dominance of non-living particles in the submicrometer range. Colloids also account for a significant portion of one of the largest stocks of organic carbon on Earth, the so-called "dissolved" organic carbon (DOC) in ocean waters (e.g., Guo \& Santschi, 1997). Dissolved organic matter (DOM), which includes DOC, is operationally defined in oceanography as material filterable through filters with a pore size in the range $0.2-0.45 \mu \mathrm{m}$. Note that such definition includes both truly soluble substances (low molecular weight compounds generally less than $1 \mathrm{~nm}$ in size), as well as insoluble macromolecular aggregates and other small colloids that pass through a $0.2-0.45 \mu \mathrm{m}$ filter (see Fig. 1). The role of DOM in optical oceanography has been traditionally associated with a category of chromophoric substances that strongly absorb radiation in the ultraviolet and blue regions of the spectrum (e.g., Bricaud, Morel, \& Prieur, 1981; Green \& Blough, 1994). These absorbing substances have been collectively referred to as yellow substance, yellow matter, gelbstoff, or colored dissolved organic matter (CDOM) (e.g., Jerlov, 1976; Kalle, 1966; Kirk, 1994; Mobley, 1994). The scattering of light by DOM has not been explicitly considered in optical analyses 
or models although the operationally defined DOM includes small colloids that can perhaps have sizable contribution to backscattering.

To our knowledge, no special experiments were made to quantify the backscattering coefficients of marine colloids with the exception of measurements by Balch et al. (2000), which were focused on viral suspensions. Mie scattering calculations for broad Junge-type size distributions of particles suggest, however, that colloidal particles can make a large contribution to the total particulate backscattering coefficient. If the modeled homogeneous spherical particles obey a Junge distribution with a slope of -4 in the diameter range from 0.002 to $100 \mu \mathrm{m}$, then the contribution of submicron particles to particulate backscattering (at $550 \mathrm{~nm}$ ) exceeds $80 \%$ if all the particles have low refractive index ( $n=1.05$ or less relative to water) and $70 \%$ if all the particles have high refractive index, $n>1.15$ (Stramski \& Kiefer, 1991). The role of submicron particles will naturally vary depending on changes in the abundance of these particles relative to larger particles, which can be tested by varying the slope of size distribution. Stramski and Kiefer (1991) made such a sensitivity analysis for three values of slope, $-3.5,-4$, and -4.5 . The $50 \%$ point of the cumulative contribution function for the backscattering coefficient at $550 \mathrm{~nm}$ was found to be reached at a particle diameter of $1.2,0.2$, and $0.16 \mu \mathrm{m}$ for the slopes of $-3.5,-4$, and -4.5 , respectively, if all the particles had the refractive index $n=1.05$ (typical of organics). For high-index particles $(n=1.20)$, the $50 \%$ point corresponded to particle diameter of $1.7,0.33$, and $0.17 \mu \mathrm{m}$ for the slopes of $-3.5,-4$, and -4.5 , respectively. As expected, there is a shift of the $50 \%$ point toward smaller particle diameters when the slope of size distribution becomes steeper. Stramski and Kiefer also showed that realistic concentrations of submicrometer particles based on measurements of Koike et al. (1990) in the size range of 0.4-1 $\mu \mathrm{m}$ can produce significant backscattering. These results along with other studies (Brown \& Gordon, 1974; Morel \& Ahn, 1991; Ulloa et al., 1994) lead to a hypothesis that colloidal particles may often be a dominant source of particulate backscattering in the upper ocean. Although the existence of colloidal particles in large numbers in the ocean has been demonstrated (e.g., Koike et al., 1990; Wells \& Goldberg, 1991), further studies focused specifically on accurate quantification of variations in the abundance, size distribution, and composition of colloidal particles and their associated scattering properties in the world's oceans are needed to quantify the roles of submicrometer particles in ocean optics.

\subsection{Liquid oil particles}

At times or in some areas of the ocean, seawater may contain various constituents from anthropogenic sources at concentrations large enough to be optically significant. One example that we will briefly address is crude oil and refined petroleum products, which are released to the marine environments during exploration, production, transportation, and consumption of petroleum. Crude oil and gas may also enter the marine waters in the form of oil droplets and gas bubbles from natural sources as a result of seepage from geologic strata beneath the seafloor, for example in North American waters of the Gulf of Mexico and Santa Barbara Channel (Brooks, Kennicutt, Fay, MacDonald, \& Sassen, 1984; Hornafius, Quigley, \& Luyendyk, 1999; Leifer \& MacDonald, 2003). Run-off from land-based sources (such as polluted rivers and waste- and storm-water streams) and natural seeps are responsible for the majority of petroleum hydrocarbon input to the world's oceans (National Research Council, 2003). Oil pollution exerts no permanent effects on vast areas of the world's oceans but can be important wherever and whenever accidental spills and chronic releases of oil occur. Many processes collectively referred to as weathering act on oil once it has been spilled and dispersed in the ocean, so eventually the material is broken down or removed from the water or is diluted to levels well below conservative concentrations of concern for environmental issues or optical considerations. However, from the time the oil enters the water until it is removed or sufficiently diluted, it can have important impacts on the environment, including perhaps the water optical properties and light backscattering.

Oil pollution of water usually occurs in the form of a thin film of oil on the sea surface (oil slick), or oil droplets and/or oily bubbles dispersed within the water column, or both. The presence of an oil slick significantly 
modifies the sea surface properties including optical reflectance (Otremba, 1994). Remote sensing of oil slicks with airborne and spaceborne sensors is playing an increasingly important role in the surveillance and mapping of oil spills (Fingas \& Brown, 1997) but this subject is beyond the scope of our discussion. We will focus just on preliminary estimates of backscattering caused by liquid oil particles suspended in seawater.

Natural dispersion of oil in the water results primarily from the action of surface waves and upper ocean turbulence which may break an oil slick into droplets and disperse them into the water column (Delvigne \& Sweeney, 1988; Li \& Garrett, 1998). Otremba and Król (2001, 2002) determined the optical properties of crude oil particles suspended in seawater from Mie scattering calculations using laboratory measurements of the size distribution and refractive index of oil particles. The size distribution of stabilized oil suspensions (more than one week old) was nearly log-normal with a maximum in the submicrometer range. The real part of refractive index relative to water was between 1.10 and 1.12 for the two types of crude oil studied (Petrobaltic from the deposit in the southern Baltic Sea and Romashkino from the Tatar province in Russia). The imaginary part varied in a broad range from about $2 \times 10^{-5}$ to $9 \times 10^{-3}$ depending on the type of oil and light wavelength. Oil particles with these properties and in-water oil concentrations of 1-2 ppm (by volume) can produce fairly large values of the scattering coefficient of about $1 \mathrm{~m}^{-1}$. These values are comparable, for example, with those measured in relatively turbid coastal waters of the Gulf of Gdansk in the Baltic Sea. As the estimated backscattering ratio for these oil suspensions is about $0.012-0.014$ at visible wavelengths, the oil concentrations of $1-2 \mathrm{ppm}$ could produce a considerable backscattering signal of $b_{\mathrm{b}}>0.01 \mathrm{~m}^{-1}$ (Otremba, Z., personal communication, 2003). The significance of these estimates is difficult to ascertain because the range of variability in the actual concentration, size distribution, and optical properties of oil particles in marine environments is poorly characterized. Under conditions of no specific discharge of oil into the sea, the background concentrations at $1 \mathrm{~m}$ depth in the open Baltic Sea and coastal waters of the Gulf of Gdansk are estimated as of $\mathrm{O}\left(10^{-3}\right)-\mathrm{O}\left(10^{-2}\right)$ ppm, respectively (Otremba, Z., personal communication, 2003). At such low concentrations, the effects on scattering can be neglected. Data available from field experiments in the North Sea indicate, however, that after release and dispersion of different types of oil, the concentration at a depth of $1 \mathrm{~m}$ can be of $\mathrm{O}(1-10) \mathrm{ppm}$ (Lunel, 1993). In that study, $99 \%$ of dispersed oil particles, representing $80-90 \%$ of the oil volume, were found in the size range from 1 to $70 \mu \mathrm{m}$ (median of the size distribution was about $20 \mu \mathrm{m}$ ). Note that these data show higher abundance of relatively large particles compared to the size distributions of the stabilized oil suspensions generated in the laboratory by Otremba and Król (2001). These differences underscore a need for further studies to better characterize the physical and optical properties of different types of oil suspended in water.

\section{Backscattering as a proxy for particulate organic matter, particle composition, and size}

The concentration of chlorophyll $a$, the principal pigment in phytoplankton, has long been utilized as an index of phytoplankton biomass in bio-optical models and remote sensing algorithms, especially in the socalled Case 1 oceanic waters whose optical properties are assumed to be dominated by phytoplankton and associated material (Gordon \& Morel, 1983; Morel \& Prieur, 1977). Example models providing formulas for the backscattering coefficient as a function of chlorophyll, which include some unavoidable speculative assumptions due to the lack of backscattering measurements, are those developed by Gordon et al. (1988) and Morel (1988). Most recently, similar relationships were shown using the particulate backscattering data determined from in situ measurements with Hydroscat-6, which were made in parallel to sampling for chlorophyll determinations (Reynolds, Stramski, \& Mitchell, 2001; Stramska, Stramski, Hapter, Kaczmarek, \& Stoń, 2003). The squared correlation coefficient (for log-transformed variables) of these relationships ranges from about 0.6 to 0.85 , and although an overall trend exists, the data show significant scatter. This is not surprising because the pigment molecules contained in phytoplankton cannot be viewed as agents directly responsible for the bulk of particulate scattering. 
Because it is the "skeleton" of carbon atoms that forms the basic framework of all classes of biologically important organic molecules, one can expect that light scattering may provide a good proxy for particulate organic carbon (POC) concentration, especially in waters dominated by organic particles. While the correlation between the particulate beam attenuation coefficient and POC has often been addressed (e.g., Bishop, 1999; Gardner, Richardson, Carlson, Hansell, \& Mishonov, 2003; Gardner, Walsh, \& Richardson, 1993; Marra, Langdon, \& Knudson, 1995), a similar idea for the particulate backscattering, $b_{\mathrm{bp}}$, has been supported only recently with the measurements in the Southern Ocean and Arabian Sea (Balch, Drapeau, Fritz, Bowler, \& Nolan, 2001; Stramski, Reynolds, Kahru, \& Mitchell, 1999). These observations are important because the backscattering coefficient belongs to the set of ocean properties derivable from ocean color (e.g., Carder, Chen, Lee, \& Hawes, 1999; Garver \& Siegel, 1997; Loisel, Bosc, Stramski, Qubelkheir, \& Deschamps, 2001; Stramski et al., 1999), which provides a basis for determining POC from satellite observations. Such satellite determinations have been demonstrated using SeaWiFS imagery in the Southern Ocean (Stramski et al., 1999).

The POC-specific backscattering coefficients ( $b_{\mathrm{b}}$ or $b_{\mathrm{bp}}$ normalized to POC concentration) can vary in the ocean because variations in particulate concentration and composition influence POC as well as the particle size, shape, and refractive index distributions, and hence $b_{\mathrm{bp}}$. Interestingly, however, carbon content in individual plankton cells is related to particle size (Montagnes, Berges, Harrison, \& Taylor, 1994; Verity et al., 1992) and refractive index (Stramski, 1999). This can contribute to good correlation between POC and $b_{\mathrm{bp}}$. Further efforts should examine the extent to which the backscattering per unit POC concentration can be considered as the quasi-stable quantity, which may require regional and seasonal constraints. In general, however, we expect that a simple direct use of $b_{\mathrm{b}}$ or $b_{\mathrm{bp}}$ as a proxy for POC will be questionable or impossible whenever inorganic particles (or other constituents such a bubbles) uncorrelated with POC make significant and variable (difficult to predict) contribution to light backscatter.

Particulate biogenic carbon is also found in the ocean in the form of calcium carbonate particles that are referred to as particulate inorganic carbon (PIC). The calcifying (coccolithophorid) phytoplankton are the most important source of optically significant PIC in the ocean. The studies of backscattering by calcifying algae suggest that PIC can be optically estimated by measuring "acid-labile backscattering" that represents a difference between the total backscattering of seawater sample and backscattering after addition of a weak acid to dissolve calcium carbonate (Balch et al., 1999; Balch et al., 2001). Owing to the ubiquitous distribution of coccolithophores, it was suggested that PIC is usually responsible for at least $\sim 10 \%$ of total particulate backscattering in most open ocean waters (Balch et al., 1999; Balch et al., 1996). In bloom situations, the coccoliths can dominate backscattering and the ocean color signal (e.g., Ackleson, Balch, \& Holligan, 1994; Holligan, Viollier, Harbour, Camus, \& Champagne-Philippe, 1983). The relationships between PIC, backscattering, and reflectance are currently a subject of active research toward retrieval of coccolith-calcite concentration from satellite imagery of ocean color (Gordon et al., 2001).

The particulate backscattering ratio, $\tilde{b}_{\mathrm{bp}}$, has recently been suggested as a sensitive proxy of the bulk index of refraction of the particulate assemblage (Boss et al., 2004a; Twardowski et al., 2001; Ulloa et al., 1994). The refractive index is itself a proxy for particulate composition. While no direct measurements of the particulate bulk index of refraction were obtained, the distribution of measured particulate backscattering ratio was consistent with expectation based on oceanographic conditions; where the retrieved index of refraction relative to water $(n)$ for phytoplankton-dominated particulate assemblages was about 1.05 while for particles near the sediment bed, $n$ was about 1.15 . With the measurements off the New Jersey coast, Boss et al. (2004a) found that the backscattering coefficient was inversely related to the ratio of chlorophyll concentration to the beam attenuation coefficient, which is consistent with the backscattering coefficient varying primarily with the particulate composition.

Twardowski et al. (2001) and Risovic (2002) used Mie theory to analyze the dependence of the particulate backscattering ratio on the particle size distribution (PSD). When PSDs were relatively steep (i.e., when small-sized particles were relatively more abundant), changes in PSD covaried with changes in $\tilde{b}_{\mathrm{bp}}$, 
and details regarding the type of PSD used and the smallest particles included in the calculations were important. For the PSDs with a relatively gentle slope, $\tilde{b}_{\mathrm{bp}}$ was not sensitive to the details of the PSD. Unfortunately, due to lack of quantitative PSD measurements extending below $1 \mu \mathrm{m}$, this subject remains to be investigated. The particulate backscattering ratio was also found to be relatively constant as function of wavelength; both in theory and measurements at a few wavelengths (Twardowski et al., 2001; Ulloa et al., 1994).

\section{The 'missing' backscattering enigma and future work}

Computation of the light scattering budget for typical non-bloom situations in open ocean waters (assumed to be free of bubbles and coccoliths) suggested that although a large fraction of particulate scattering coefficient (tens of percent) appears to come from living plankton cells, particularly phytoplankton and heterotrophic bacteria, only a small fraction of the particulate backscattering coefficient (up to a dozen or so percent) can be explained by these microorganisms (Morel \& Ahn, 1991; Stramski \& Kiefer, 1991). For typical concentrations of plankton cells, heterotrophic bacteria were suggested to be the most important backscatterers among microorganisms, which implied an even smaller role for pigmented phytoplankton (generally $<10 \%$ contribution). This result, if indeed the case, implies some paradox because the backscattered light is being used as the "signal" in ocean color remote sensing of phytoplankton pigments. The successful estimation of pigments from remote sensing must then be attributed to significant covariation of phytoplankton and other constituents that dominate backscattering, the predominant role of absorption (rather than backscattering) in driving changes in ocean color, or both.

The portion of backscattering unaccounted for by microorganisms has been referred to as 'missing' backscattering. The submicron (colloidal) non-living particles were suggested as the likely component responsible for most of the particulate backscattering in the open ocean under non-bloom conditions because such colloids satisfy a requirement of making a relatively higher percent contribution to particulate backscattering than to total particulate scattering coefficient (Morel \& Ahn, 1991; Stramski \& Kiefer, 1991); a suggestion also contained in early models of light scattering by marine particles (Brown \& Gordon, 1974). Importantly, the concentrations of submicron particles in the size range of $0.4-1 \mu \mathrm{m}$, which were actually measured in the ocean by Koike et al. (1990), were shown to provide a closure in the Stramski and Kiefer budget for both the scattering and backscattering coefficients. The marine colloids are largely of organic origin (e.g., Leppard et al., 1997; Wells \& Goldberg, 1991) but the significance of minerals for light backscattering from the colloidal (clay) and/or larger particle sizes (silt) cannot be excluded.

The role of non-living particles (both organic and minerogenic) was recently supported with simulations of the ocean inherent optical properties based on a particle optical data set (Stramski et al., 2001). The size distribution of the non-living particles was assumed to obey a -4 power law and the planktonic community consisted of 18 distinct taxonomic groups or species. The most striking result from these simulations is that microorganisms and non-living particles play different roles in particulate absorption and backscattering. Phytoplankton were the most important source of absorption as all the non-living particles contributed about $30 \%$ to particulate absorption at $440 \mathrm{~nm}$ in the simulated water body that contained about 0.18 $\mathrm{mg} \mathrm{Chl} a$ per $\mathrm{m}^{3}$. This is a realistic scenario for open ocean waters. Under this scenario, however, the non-living particles totally dominated the particulate backscattering coefficient with very little contribution $(\sim 2-3 \%)$ coming from all the microorganisms. The mineral particles with high refractive index, although numerically three times less abundant than low-index organic detritus, were by far the most important source of backscattering in these simulations $(>80 \%)$. Clean bubbles without the surface coating were included in the simulations at average concentrations representative of near surface waters under winds of $10 \mathrm{~m} \mathrm{~s}^{-1}$ and they made a contribution of $4-7 \%$ to particulate backscattering. We note that the non-living 
particles would still dominate the particulate backscattering in the simulated water body even if the phytoplankton backscattering cross-sections from the Stramski et al. (2001) data set used in those simulations are too low by a factor of 5 or even 10 (see the comparison of Stramski et al. and Vaillancourt et al. data in Section 3.4 above). No generalization from the example simulations by Stramski et al. (2001) can be made, however, because those results depend largely on the assumed proportions between the concentrations of different types of particles in the simulated water body.

The potential for the dominant role of non-living particles in backscattering has been supported by a recent study of Atlantic shelf waters off New England, in which flow cytometry measurements of individual particles were combined with Mie scattering model to determine the effects of the various types of particles on the inherent optical properties at $488 \mathrm{~nm}$ (Green et al., 2003). This study showed that eukaryotic phytoplankton were responsible for the majority of both total particulate absorption and total particulate scattering in surface waters during spring and summer seasons. However, the particulate backscattering was dominated by minerals in the spring and by both detritus and minerals in the summer.

Although it is tempting to propose that in most non-bloom surface waters over the vast open ocean areas, the small-sized non-living particles are a major source of particulate backscattering due to their very high concentrations, a complete explanation of the 'missing' backscattering is certainly far more complicated. Although the concentration of colloids is generally high, it can vary significantly (Wells \& Goldberg, 1994; Yamasaki et al., 1998). The concentrations of other particles contributing to backscattering are also variable, so the relative proportions between colloids and other particles can probably vary quite considerably. The scenario that phytoplankton contribution to backscattering is small will not hold when coccolithophorid phytoplankton are present in water in sufficient concentrations (Balch et al., 1996) or during blooms of other species. In addition, the issue of the contribution of phytoplankton to backscattering is still open because of uncertainty in the values of backscattering efficiencies of individual cells. These uncertainties are indicated by differences between predictions from the optical models of homogeneous spheres and layered spheres (Kitchen \& Zaneveld, 1992) as well as between the homogeneous sphere models and measurements such as those by Volten et al. (1998) and Vaillancourt et al. (2004). Kitchen and Zaneveld (1992) showed that a three-layered sphere model increases scattering at all angles except the near-forward by more than one order of magnitude compared to a homogeneous sphere model. As the layered sphere model of phytoplankton populations produced a realistic volume scattering function, they suggested that it is not necessary to have high concentrations of submicron particles or mineral particles to match the backscattering coefficient in the region of central ocean gyre. In another work with homogeneous, twolayered, and three-layered sphere models, Zaneveld and Kitchen (1995) showed a 3-fold variation in the backscattering coefficient for some models. However, their work also indicated that the magnitude of the modeled backscattering depends strongly on the assumed thickness of the outer layer in the layered sphere model. In addition, the backscattering will depend on shape and internal structure characteristics of phytoplankton cells. Therefore, it is not yet clear to what extent the two-layered or three-layered sphere models improve the estimates of phytoplankton backscattering properties and phytoplankton role in the question of 'missing' backscattering in the ocean. It seems that further advances will have to rely primarily on experimental efforts to determine the backscattering properties of the various plankton species.

The role of mineral particles also requires an improved understanding and quantification. There is circumstantial evidence that these particles can dominate the particulate backscattering not only in coastal but perhaps also at times in some open ocean waters. It is well known that mineral particles can represent a significant fraction of suspended particulate matter in coastal waters, which is related to river discharge of sediments, coastal erosion by wave and current action, and bottom resuspension. Much of the river transported material is efficiently trapped in coastal ocean on the continental shelves and slopes. Nevertheless, it is possible that mineral particles, especially in the size range of clay and small silt, can exist in the open ocean in significant enough concentrations (at least sporadically) to cause much of the particulate backscattering. The long-range atmospheric transport and deposition of mineral dust onto the ocean 
and advection with currents provide source mechanisms of these particles for open ocean regions. Laboratory measurements aiming at the quantification of the absorption and scattering properties of mineral particles suspended in water, covering a range of mineral and chemical compositions and size distributions of particulate assemblages, have been initiated lately but backscattering measurements were not made (Babin \& Stramski, 2004; Stramski, Woźniak, \& Flatau, 2004). More experiments of this kind, including backscattering measurements, are needed.

Bubbles can dominate the backscattering at shallow depths whenever wave breaking occurs (Terrill et al., 2001). However, these effects will have highly intermittent nature as bubble concentration fluctuates strongly in time and space over a range of scales, including short temporal scales of $\mathrm{O}(1) \mathrm{s}$ and small spatial scales of $\mathrm{O}(1) \mathrm{m}$ in the horizontal and $\mathrm{O}(0.1) \mathrm{m}$ in the vertical. This variability is poorly characterized and needs to be investigated. In addition, it is unclear what the concentrations and variability of small-sized bubbles (from $<1 \mu \mathrm{m}$ to $\sim 20 \mu \mathrm{m}$ ) might be. So far, only bubbles larger than $20 \mu \mathrm{m}$ were amenable to the existing techniques for in situ bubble detection. If future studies discover the small-sized bubbles in sufficient quantities, especially bubbles stabilized with surface coating (e.g., Johnson \& Cooke, 1981), this may implicate an important source of the 'missing' backscattering (Zhang et al., 2002).

In summary, at any time or location in the ocean the light backscattering may be dominated by different types of particles or by bubbles. Unfortunately, many types of particles that show significant potential for large contribution to backscattering, such as colloids and non-living biogenic and minerogenic particles, have been among the least studied optical constituents of seawater. Although considerable attention in the past has been devoted to the optics of phytoplankton and other microorganisms, we still face challenges for more accurate quantification of backscattering on actual biological cells that exhibit complex shapes and internal structures. The studies of the optical effects of bubbles have just begun in recent years. It will take much effort to quantify these effects as bubble concentrations near the sea surface show large fluctuations over small spatial and temporal scales, which requires a description in statistical or stochastic terms. Unless there is an immediate significant increase and expansion in basic research to quantify the fundamental interactions of light with very many constituents of seawater, we will continue to have limited understanding of the roles played by the various constituents in ocean optics including light backscattering for many years to come. Natural seawater is a very complex optical medium containing a great variety of particle types and soluble species that differ in optical properties, and their concentration and composition vary with time and location in the ocean. The ocean optics science must progress beyond the traditional overly simplified description of seawater, which has been based only on a few constituent categories defined broadly as molecular water, suspended particles (phytoplankton and detritus), and dissolved organic matter. Further development of an understanding of the substantial variability in ocean optical properties and its sources will require a reductionist approach for quantifying the optical properties of many particle types and their effects on bulk ocean optical properties. The optical measurements both in the laboratory and at sea will have to be conducted in parallel with detailed characterization of water composition including plankton species composition, detritus properties, particle mineralogy, particle concentrations over the entire optically significant size range including colloids, as well as chemistry of particles and chromophoric soluble substances. The complexities and challenges of the reductionist approach should not deter us from pursuing the proper course in future research.

\section{Acknowledgements}

This work was supported by the Office of Naval Research (ONR) Hyperspectral Coastal Ocean Dynamics Experiments (HyCODE) program (Grants N00014-02-1-0190 to D.S. and N00014-03-1-0339 to E.B.) and NASA (Grants NAG5-12513 to D.B. and NAG5-31363 to K.J.V.). We thank R. Zaneveld for valuable discussion and F. Fell and anonymous reviewer for comments on the manuscript. 


\section{References}

Aas, E. (1996). Refractive index of phytoplankton derived from its metabolite composition. Journal of Plankton Research, 18, 2223-2249.

Ackleson, S. G., Balch, W. M., \& Holligan, P. M. (1994). The response of water-leaving radiance to particulate calcite and pigment concentration: A model for Gulf of Maine coccolithophore blooms. Journal of Geophysical Research, 99, 7483-7499.

Ackleson, S. G., \& Spinrad, R. W. (1988). Size and refractive index of individual particulates: a flow cytometric approach. Applied Optics, 27, 1270-1277.

Ahn, Y.-H., Bricaud, A., \& Morel, A. (1992). Light backscattering efficiency and related properties of some phytoplankters. Deep-Sea Research Part A, 39, 1835-1855.

Atkins, W. R. G., \& Poole, H. H. (1952). An experimental study of the scattering of light by natural waters. Proceedings of the Royal Society (London) Series B, 140, 321-338.

Babin, M., \& Stramski, D. (2004). Variations in the mass-specific absorption coefficient of mineral particles suspended in water. Limnology and Oceanography, 49, 756-767.

Balch, W. M., Drapeau, D. T., Cucci, T. L., Vaillancourt, R. V., Kilpatrick, K. A., \& Fritz, J. J. (1999). Optical backscattering by calcifying algae: Separating the contribution of particulate inorganic and organic carbon fractions. Journal of Geophysical Research, 104, 1541-1558.

Balch, W. M., Drapeau, D. T., Fritz, J. J., Bowler, B. C., \& Nolan, J. (2001). Optical backscattering in the Arabian Sea-continuous underway measurements of particulate inorganic and organic carbon. Deep-Sea Research Part I, 48, $2423-2452$.

Balch, W. M., Holligan, P. M., Ackleson, S. G., \& Voss, K. J. (1991). Biological and optical properties of mesoscale coccolithophore blooms in the Gulf of Maine. Limnology and Oceanography, 36, 629-643.

Balch, W. M., Kilpatrick, K. A., Holligan, P. M., Harbour, D., \& Fernandez, E. (1996). The 1991 coccolithophore bloom in the central north Atlantic.2. Relating optics to coccolith concentration. Limnology and Oceanography, 41, 1684-1696.

Balch, W. M., Vaughn, J., Novotny, J., Drapeau, D. T., Vaillancourt, R., Lapierre, J., \& Ashe, A. (2000). Light scattering by viral suspensions. Limnology and Oceanography, 45, 492-498.

Batchelor, G. K. (1959). Small-scale variations of convected quantities like temperature in turbulent fluids. Journal of Fluid Mechanics, $5,113-133$.

Beardsley, G. F. Jr., (1968). Mueller scattering matrix of sea water. Journal of the Optical Society of America, $58,52-57$.

Berry, L. G., Mason, B., \& Dietrich, R. V. (1983). Mineralogy. Concepts, Descriptions, Determinations (second ed.). New York: W.H. Freeman and Company.

Bergh, Ø., Børsheim, K. Y., Bratbak, G., \& Heldal, M. (1989). High abundance of viruses found in aquatic environments. Nature, 340, $467-468$

Bishop, J. K. B. (1999). Transmissometer measurement of POC. Deep-Sea Research Part I, 46, 353-369.

Bogucki, D. J., Domaradzki, J. A., Stramski, D., \& Zaneveld, J. R. V. (1998). Comparison of near-forward light scattering on oceanic turbulence and particles. Applied Optics, 37, 4669-4677.

Bogucki, D., Domaradzki, J. A., \& Yeung, P. K. (1997). Direct numerical simulations of passive scalars with Pr $>1$ advected by turbulent flow. Journal of Fluid Mechanics, 343, 111-130.

Bohren, C. F., \& Huffman, D. R. (1983). Absorption and scattering of light by small particles. New York: J. Wiley and Sons.

Boss, E., \& Pegau, W. S. (2001). Relationship of light scattering at an angle in the backward direction to the backscattering coefficient. Applied Optics, 40, 5503-5507.

Boss, E., Collier, R., Larson, G., Fennel, K., \& Pegau, W.S. (2004). Measurements of spectral optical properties and their relation to biogeochemical variables and processes in Crater Lake National Park, OR. Hydrobiologia (in press).

Boss, E., Pegau, W. S., Lee, M., Twardowski, M. S., Shybanov, E., Korotaev, G., \& Baratange, F. (2004a). Particulate backscattering ratio at LEO 15 and its use to study particle composition and distribution. Journal of Geophysical Research, 109, C01014, doi:10.1029/2002JC001514.

Bricaud, A., \& Morel, A. (1986). Light attenuation and scattering by phytoplanktonic cells: A theoretical modeling. Applied Optics, 25, 571-580.

Bricaud, A., Morel, A., \& Prieur, L. (1981). Absorption by dissolved organic matter of the sea (yellow substance) in the UV and visible domains. Limnology and Oceanography, 26, 43-53.

Bricaud, A., Morel, A., \& Prieur, L. (1983). Optical efficiency factors of some phytoplankters. Limnology and Oceanography, 28, 816-832.

Brooks, J. M., Kennicutt, M. C., II, Fay, R. R., MacDonald, I. J., \& Sassen, R. (1984). Thermogenic gas hydrates in the Gulf of Mexico. Science, 223, 696-698.

Brown, O. B., \& Gordon, H. R. (1973). Two component Mie scattering models of Sargasso Sea particles. Applied Optics, 12, 2461-2465.

Brown, O. B., \& Gordon, H. R. (1974). Size-refractive index distribution of clear coastal water particulates from light scattering. Applied Optics, 13, 2874-2881. 
Buffle, J., \& van Leeuwen, H. P. (1992). Environmental Particles (vol. 1). Chelsea: Lewis Publishers.

Buiteveld, H., Hakvoort, J. H. M., \& Donze, M. (1994). The optical properties of pure water. In J. S. Jaffe (Ed.), Ocean optics XII. Proceedings SPIE (Vol. 2258, pp. 174-183). Bellingham: The Society of Photo-Optical Instrumentation Engineers.

Bukata, R. P., Jerome, J. H., Kondratyev, K. Ya., \& Pozdnyakov, D. V. (1995). Optical properties and remote sensing of inland and coastal waters. Boca Raton: CRC Press.

Cabannes, J. (1929). La diffusion moleculaire de la lumiére. Paris: Les Presses Universitaires de France.

Carder, K. L., Chen, F. R., Lee, Z., \& Hawes, S. K. (1999). Semianalytical Moderate-Resolution Imaging Spectrometer algorithms for chlorophyll a and absorption with bio-optical domains based on nitrate depletion temperatures. Journal of Geophysical Research, 104, 5403-5421.

Chilton, F., Jones, D. D., \& Talley, W. K. (1969). Imaging properties of light scattered by the sea. Journal of the Optical Society of America, 59, 891-898.

Chin, W.-C., Orellana, M. V., \& Verdugo, P. (1998). Spontaneous assembly of marine dissolved organic matter into polymer gels. Nature, 391, 568-572.

Delvigne, G. A. L., \& Sweeney, C. E. (1988). Natural dispersion of oil. Oil \& Chemical Pollution, 4, 281-310.

Detwiler, A., \& Blanchard, D. C. (1978). Ageing and bursting bubbles in trace-contaminated water. Chemical Engineering Science, 33, $9-13$.

Dillon, T. M. (1984). The energetics of overturning structures: Implications for the theory of fossil turbulence. Journal of Physical Oceanography, 14, 541-549.

Duntley, S. Q. (1963). Light in the sea. Journal of the Optical Society of America, 53, 214-233.

Einstein, A. (1910). Theorie der Opaleszenz von homogenen Flüssigkeiten und Flüssigkeitsgemischen in der Nähe des kritischen Zustandes. Annalen der Physik, 33, 1275-1298.

Fargion, G. S. \& McClain, C. R. (2001). SIMBIOS project 2000 annual report. Greenbelt: NASA Goddard Space Flight Center.

Fingas, M. F., \& Brown, C. E. (1997). Review of oil spill remote sensing. Spill Science and Technology Bulletin, 4, $199-208$.

Fournier, G., \& Forand, J. L. (1994). Analytic phase function for ocean water. In J. S. Jaffe (Ed.), Ocean Optics XII. Proceedings SPIE (Vol. 2258, pp. 194-201). Bellingham: The Society of Photo-Optical Instrumentation Engineers.

Frouin, R., Schwindling, M., \& Deschamps, P-Y. (1996). Spectral reflectance of sea foam in the visible and near-infrared: In situ measurements and remote sensing implications. Journal of Geophysical Research, 101, 14361-14371.

Fry, E. (1974). Absolute calibration of a scatterance meter. In R. J. Gibbs (Ed.), Suspended Solids in Water (pp. 101-109). New York: Plenum.

Fry, E. S., \& Voss, K. J. (1985). Measurements of the Mueller matrix for phytoplankton. Limnology and Oceanography, 30, $1322-1326$.

Gardner, W. D., Richardson, M. J., Carlson, C. A., Hansell, D., \& Mishonov, A. V. (2003). Determining true particulate organic carbon: Bottles, pumps, and methodologies. Deep-Sea Research Part II, 50, 655-674.

Gardner, W. D., Walsh, I. D., \& Richardson, M. J. (1993). Biophysical forcing of particle production and distribution during a spring bloom in the North Atlantic. Deep Sea-Research Part II, 40, 171-195.

Garver, S. A., \& Siegel, D. A. (1997). Inherent optical property inversion of ocean color spectra and its biogeochemical interpretation. 1. Time series from the Sargasso Sea. Journal of Geophysical Research, 102, 18607-18625.

Gordon, H. R. (1974). Mie-theory models of light scattering by ocean particulates. In J. R. Gibbs (Ed.), Suspended Solids in Water (pp. 73-86). New York: Plenum Press.

Gordon, H. R., Boynton, G. C., Balch, W. M., Groom, S. B., Harbour, D. S., \& Smyth, T. J. (2001). Retrieval of coccolithophore calcite concentration from SeaWiFS imagery. Geophysical Research Letters, 28, 1587-1590.

Gordon, H. R., Brown, O. B., Evans, R. H., Brown, J. W., Smith, R. C., Baker, K. S., et al. (1988). A semi-analytic radiance model of ocean color. Journal of Geophysical Research, 93, 10909-10924.

Gordon, H. R., Brown, O. B., \& Jacobs, M. M. (1975). Computed relationships between the inherent and apparent optical properties of a flat homogeneous ocean. Applied Optics, 14, 417-427.

Gordon, H. R., \& Du, T. (2001). Light scattering by nonspherical particles: Application to coccoliths detached from Emiliania huxleyi. Limnology and Oceanography, 46, 1438-1454.

Gordon, H. R., \& Morel, A. (1983). Remote assessment of ocean color for interpretation of satellite visible imagery - A review. In R. T. Barber, C. N. K. Mooers, M. J. Bowman, \& B. Zeitzschel (Eds.), Lecture Notes on Coastal and Estuarine Studies (pp. 114 pp). New York: Springer-Verlag.

Green, S. A., \& Blough, N. V. (1994). Optical absorption and fluorescence properties of chromophoric dissolved organic matter in natural waters. Limnology and Oceanography, 39, 1903-1916.

Green, R. E., Sosik, H. M., Olson, R. J., \& DuRand, M. D. (2003). Flow cytometric determination of size and complex refractive index for marine particles: Comparison with independent and bulk estimates. Applied Optics, 42, 526-541.

Guo, L., \& Santschi, P. H. (1997). Composition and cycling of colloids in marine environments. Reviews of Geophysics, 35, 17-40.

Haltrin, V. I. (1999). One-parameter two-term Henyey-Greenstein phase function for light scattering in seawater. Applied Optics, 41, 1022-1028. 
Haltrin, V.I., Lee, M.E., Shybanov, E.B., Arnone, R.A., Weidemann, A.D., Mankovsky, V.I., Pegau, W.S., \& Ladner, S.D. (2002). Relationship between backscattering and beam scattering coefficients derived from new measurements of light scattering phase functions. In Ocean Optics XVI Conference, Santa Fe, New Mexico, November 18-22, CD-ROM.

Henyey, L. C., \& Greenstein, J. L. (1941). Diffuse radiation in the galaxy. Astrophysical Journal, 93, 70-83.

Hodara, H. (1973). Experimental results of small angle scattering. In Electromagnetics of the sea, AGARD Conference Proceedings (Vol. 81, pp. 3.4-1-3.4-17). Neuilly-Sur-Seine: NATO.

Hodkinson, J. R. (1963). Light scattering and extinction by irregular particles larger than the wavelength. In M. Kerker (Ed.). Electromagnetic Scattering (Vol. 5, pp. 87-100). New York: Pergamon.

Holland, A. C., \& Gagne, G. (1970). The scattering of polarized light by polydisperse systems of irregular particles. Applied Optics, 9 , 1113-1121.

Holligan, P. M., Viollier, M., Harbour, D. S., Camus, P., \& Champagne-Philippe, M. (1983). Satellite and ship studies of coccolithophore production along a continental shelf edge. Nature, 304, 339-342.

Honey, R. C. \& Sorensen, G. P. (1970). Optical absorption and turbulence induced narrow-angle forward scatter in the sea. In Electromagnetics of the sea, AGARD Conference Proceedings (Vol. 77, pp. 39.1-39.7). Neuilly-Sur-Seine: NATO.

Hornafius, J. S., Quigley, D. C., \& Luyendyk, B. P. (1999). The world's most spectacular marine hydrocarbon seeps (Coal Oil Point, Santa Barbara Channel, California): Quantification of emissions. Journal of Geophysical Research, 104, 20703-20711.

Iturriaga, R., \& Siegel, D. A. (1989). Microspectrophotometric characterization of phytoplankton and detrital absorption properties in the Sargasso Sea. Limnology and Oceanography, 34, 1706-1726.

Jackson, G. A., Maffione, R., Costello, D. K., Alldredge, A. L., Logan, B. E., \& Dam, H. G. (1997). Particle size spectra between 1 mm and $1 \mathrm{~cm}$ at Monterey Bay determined using multiple instruments. Deep-Sea Research I, 44, 1739-1767.

Jerlov, N. G. (1961). Optical measurements in the eastern North Atlantic. Meddelanden Oceanografiska Institutionen Göteborg, Serie B, 8, 1-40.

Jerlov, N. G. (1976). Marine Optics. Amsterdam: Elsevier.

Johnson, B. D., \& Cooke, R. C. (1981). The generation of stabilized microbubbles in sea water. Science, 213, $209-211$.

Jonasz, M., \& Prandtke, H. (1986). Comparison of measured and computed light scattering in the Baltic. Tellus, 38B, $144-157$.

Jonasz, M. (1990). Volume scattering function measurement error: Effect of angular resolution of the nephelometer. Applied Optics, 29, $64-70$.

Kalle, K. (1966). The problem of the gelbstoff in the sea. Oceanography and Marine Biology, Annual Reviews, 4, 91-104.

Kattawar, G. W. (1975). A three-parameter analytic phase function for multiple scattering calculations. Journal of Quantitative Spectroscopy and Radiative Transfer, 15, 839-849.

Kattawar, G. W. (1994). Polarization of light in the ocean. In R. W. Spinrad, K. L. Carder, \& M. J. Perry (Eds.), Ocean Optics (pp. 202-225). New York: Oxford University Press.

Kerker, M., Chew, H., McNulty, P. J., Kratohvil, J. P., Cooke, D. D., Sculley, M., et al. (1979). Light scattering and fluorescence by small particles having internal structure. Journal of Histochemistry and Cytochemistry, 27, 250-263.

Kitchen, J. C., \& Zaneveld, J. R. V. (1992). A three-layered sphere model of the optical properties of phytoplankton. Limnology and Oceanography, 37, 1680-1690.

Kirk, J. T. O. (1994). Light and Photosynthesis in Aquatic Environments (second ed.). Cambridge: University Press.

Koike, I. S., Hara, S., Terauchi, K., \& Kogure, K. (1990). Role of sub-micron particles in the ocean. Nature, 345, $242-244$.

Kopilevich, Y. I., Aleksejev, N. V., Kurasov, B. V., \& Yakovlev, V. A. (1994). Diagnostics of sea-water turbulence by small-angle light scattering. In J. S. Jaffe (Ed.), Ocean Optics XII. Proceedings SPIE (Vol. 2258, pp. 822-830). Bellingham: The Society of PhotoOptical Instrumentation Engineers.

Kopilevich, Y. I., \& Feigels, V. I. (1994). Theoretical modeling for backscattered pulse kinetics and interpretation of some anomalies in lidar remote sensing data. In J. S. Jaffe (Ed.), Ocean Optics XII. Proceedings SPIE (Vol. 2258, pp. 458-471). Bellingham: The Society of Photo-Optical Instrumentation Engineers.

Kopelevich, O. V. (1983). Experimental data of the optical properties of seawater (In Russian). In A. S. Monin (Ed.), Ocean Optics, I. Physical Ocean Optics (pp. 166-208). Moscow: Nauka.

Kratohvil, J. P., Dezelic, G., Kerker, M., \& Matijevic, E. (1962). Calibration of light-scattering instruments: A critical survey. Journal of Polymer Science, 57, 59-78.

Kullenberg, G. (1968). Scattering of light by Sargasso Sea water. Deep-Sea Research, 15, 423-432.

Kullenberg, G. (1974). Observed and computed scattering functions. In N. G. Jerlov \& E. Steeman-Nielsen (Eds.), Optical Aspects of Oceanography (pp. 25-49). New York: Academic Press.

Kullenberg, G. (1984). Observations of light scattering functions in two oceanic areas. Deep-Sea Research, 31, $295-316$.

Lee, M. E., \& Lewis, M. R. (2003). A new method for the measurement of the optical volume scattering function in the upper ocean. Journal of Atmospheric and Oceanic Technology, 20, 563-571.

Leifer, I., \& MacDonald, I. (2003). Dynamics of the gas flux from shallow gas hydrate deposits: Interaction between oily hydrate bubbles and the oceanic environment. Earth and Planetary Science Letters, 210, 411-424. 
Leppard, G. G., West, M. M., Flanningan, D. T., Carson, J., \& Lott, J. N. A. (1997). A classification scheme for marine organic colloids in the Adriatic Sea: Colloid speciation by transmission electron microscopy. Canadian Journal of Fisheries and Aquatic Sciences, 54, 2334-2349.

Li, W. K. W. (1995). Composition of ultraphytoplankton in the central North Atlantic. Marine Ecology Progress Series, $122,1-8$.

Li, M., \& Garrett, C. (1998). The relationships between oil droplet size and upper ocean turbulence. Marine Pollution Bulletin, 36, 961-970.

Loisel, H., Bosc, E., Stramski, D., Qubelkheir, K., \& Deschamps, P.-Y. (2001). Seasonal variability of the backscattering coefficient in the Mediterranean Sea based on satellite SeaWiFS imagery. Geophysical Research Letters, 28, 4203-4206.

Lunel, T. (1993). Dispersion: Oil droplet size measurements at sea. In Proceedings of the 16th Arctic and Marine Oilspill Program (AMOP) Technical Seminar (pp. 1023-1056). Ottawa: Environment Canada.

Maffione, R. A., \& Dana, D. R. (1997). Instruments and methods for measuring the backward-scattering coefficient of ocean waters. Applied Optics, 36, 6057-6067.

Maffione, R. A., \& Honey, R. C. (1992). Instrument for measuring the volume scattering function in the backward direction. In G. D. Gilbert (Ed.), Ocean Optics XI. Proceedings SPIE (Vol. 1750, pp. 15-26). Bellingham: The Society of Photo-Optical Instrumentation Engineers.

Mankovsky, V. I., \& Haltrin, V. I. (2002). Phase functions of light scattering measured in waters of world ocean and Lake Baykal. In 2002 IEEE International Geosciences and Remote Sensing Symposium and the 24th Canadian Symposium on Remote Sensing, Proceedings on CD ROM, Paper\#I2E09_1759. Toronto: Library of Congress Number 2002.

Maranger, R., \& Bird, D. F. (1995). Viral abundance in aquatic systems: A comparison between marine and fresh waters. Marine Ecology Progress Series, 121, 217-226.

Marra, J., Langdon, C., \& Knudson, C. A. (1995). Primary production, water column changes, and the demise of Phaeocystis bloom at the Marine Light-Mixed Layers site $\left(59^{\circ} \mathrm{N}, 21^{\circ} \mathrm{W}\right)$ in the northeast Atlantic Ocean. Journal of Geophysical Research, 100, 6633-6643.

McCave, I. N. (1983). Particulate size spectra, behavior, and origin of nepheloid layers over the Nova Scotian continental rise. Journal of Geophysical Research, 88, 7647-7666.

Medwin, H., \& Clay, C. S. (1998). Fundamentals of Acoustical Oceanography. Boston: Academic Press.

Meyer, R. A. (1979). Light scattering from biological cells: Dependence of backscatter radiation on membrane thickness and refractive index. Applied Optics, 18, 585-588.

Mie, G. (1908). Beiträge zur Optik trüber Medien, speziell kolloidaler Metallösungen. Annalen der Physik, 25, 377-445.

Mishchenko, M. I., Hovenier, J. W., \& Travis, L. D. (2000). Light scattering by nonspherical particles. Theory, measurements, and applications. San Diego: Academic Press.

Mobley, C. D. (1994). Light and water. Radiative transfer in natural waters. San Diego: Academic Press.

Mobley, C. D. (1995). The Optical Properties of Water. In M. Bass, E. W. Van Stryland, D. R. Williams, \& W. L. Wolf (Eds.), Handbook of Optics. Fundamentals, Techniques, and Design (Vol. I, pp. 43.3-43.56). New York: McGraw-Hill.

Mobley, C. D., \& Stramski, D. (1997). Effects of microbial particles on oceanic optics: Methodology for radiative transfer modeling and example simulations. Limnology and Oceanography, 42, 550-560.

Mobley, C. D., Sundman, L. K., \& Boss, E. (2002). Phase function effects on oceanic light fields. Applied Optics, 41, 1035-1050.

Montagnes, D. J., Berges, J. A., Harrison, P. J., \& Taylor, F. J. R. (1994). Estimation of carbon, nitrogen, protein, and chlorophyll a from volume in marine phytoplankton. Limnology and Oceanography, 39, 1044-1060.

Moore, K. D., Voss, K. J., \& Gordon, H. R. (2000). Spectral reflectance of whitecaps: Their contribution to water leaving radiance. Journal of Geophysical Research, 105, 6493-6499.

Morel, A. (1966). Etude expérimentale de la diffusion de la lumière par l'eau, le solutions de chlorure de sodium et l'eau de mer optiquement pure. Journal de Chimie Physique, 10, 1359-1366.

Morel, A. (1973). Diffusion de la lumière par les eaux de mer. Résultats expérimentaux et approche théorique. In Optics of the Sea, AGARD Lecture Series 61, Sect. 3 (pp. 1-76). Neuilly-sur-Seine: NATO.

Morel, A. (1974). Optical properties of pure water and pure sea water. In N. G. Jerlov \& E. Steeman-Nielsen (Eds.), Optical Aspects of Oceanography (pp. 1-24). New York: Academic Press.

Morel, A. (1988). Optical modeling of the upper ocean in relation to its biogenous matter content (Case I waters). Journal of Geophysical Research, 93, 10749-10768.

Morel, A., \& Ahn, Y.-H. (1990). Optical efficiency factors of free living marine bacteria: Influence of bacterioplankton upon the optical properties and particulate organic carbon in oceanic waters. Journal of Marine Research, 48, 145-175.

Morel, A., \& Ahn, Y.-H. (1991). Optics of heterotrophic nanoflagellates and ciliates. A tentative assessment of their scattering role in oceanic waters compared to those of bacterial and algal cells. Journal of Marine Research, 49, 177-202.

Morel, A. \& Bricaud, A. (1986). Inherent optical properties of algal cells including picoplankton: Theoretical and experimental results. In T. Platt \& W.K.W. Li (Eds.), Photosynthetic picoplankton (pp. 521-559). Ottawa: Canadian Bulletin of Fisheries and Aquatic Sciences, 214. 
Morel, A., \& Gentili, B. (1991). Diffuse reflectance of oceanic waters: Its dependence on Sun angle as influenced by the molecular scattering contribution. Applied Optics, 30, 4427-4438.

Morel, A., \& Prieur, L. (1977). Analysis of variations in ocean color. Limnology and Oceanography, 22, 709-722.

Mugnai, A., \& Wiscombe, W. (1989). Scattering from nonspherical Chebyshev particles. 3: Variability in angular scattering patterns. Applied Optics, 28, 3061-3073.

National Research Council (2003). Oil in the Sea III. Inputs, fates, and effects. Washington, DC: The National Academies Press.

O'Hern, T. J., D'Agostino, L., \& Acosta, A. J. (1988). Comparison of holographic and Coulter Counter measurements of cavitation nuclei in the ocean. Transactions of the ASME, Journal of Fluids Engineering, 110, 200-207.

Oishi, T. (1990). Significant relationship between the backward scattering coefficient of seawater and the scatterance at 120 degrees. Applied Optics, 29, 4658-4665.

Otremba, Z. (1994). The influence of an oil-film covered sea surface on the reflection and upward transmission of light. Oceanologia, $36,137-154$.

Otremba, Z., \& Król, T. (2001). Light attenuation parameters of polydisperse oil-in-water emulsion. Optica Applicata, XXXI, 599-600.

Otremba, Z., \& Król, T. (2002). Modeling of the crude oil suspension impact on inherent optical parameters of coastal seawater. Polish Journal of Environmental Studies, 11, 407-411.

Ozmidov, R. V. (1965). On the turbulent exchange in a stably stratified ocean. Izvestiya, Atmospheric and Oceanic Physics, 1, $493-497$.

Petzold, T. J. (1972). Volume scattering functions for selected ocean waters, Rep. 72-78. La Jolla: Scripps Institution of Oceanography.

Pritchard, B. S., \& Elliot, W. G. (1960). Two instruments for atmospheric optics measurements. Journal of the Optical Society of America, 50, 191-202.

Quinby-Hunt, M. S., Hunt, A. J., Lofftus, K., \& Shapiro, D. (1989). Polarized-light scattering studies of marine Chlorella. Limnology and Oceanography, 34, 1587-1600.

Reynolds, R. A., Stramski, D., \& Mitchell, B. G. (2001). A chlorophyll-dependent semianalytical reflectance model derived from field measurements of absorption and backscattering coefficients within the Southern Ocean. Journal of Geophysical Research, 106, 7125-7138.

Risovic, D. (2002). Effect of suspended particulate-size distribution on the backscattering ratio in the remote sensing of seawater. Applied Optics, 41, 7092-7101.

Santschi, P. H., Balnois, E., Wilkinson, K. J., Zhang, J., \& Buffle, J. (1998). Fibrillar polysaccharides in marine macromolecular organic matter as imaged by atomic force microscopy and transmission electron microscopy. Limnology and Oceanography, 43, 896-908.

Sasaki, T., Okami, N., Oshiba, G., \& Watanabe, S. (1960). Angular distribution of scattered light in deep sea water. Records of Oceanographic Works in Japan, 5(2), 1-10.

Schuerman, D. W., Wang, R. T., Gustafson, B. A. S., \& Schaefer, R. W. (1981). Systematic studies of light scattering. 1: Particle shape. Applied Optics, 20, 4039-4050.

Sheldon, R. W., Prakash, A., \& Sutcliffe, W. H. (1972). The size distributions of particles in the ocean. Limnology and Oceanography, 17, 327-340.

Shifrin, K. S. (1988). Physical optics of ocean water. New York: American Institute of Physics.

Smith, R. C., \& Baker, K. (1981). Optical properties of the clearest natural waters. Applied Optics, 20, $177-184$.

Smoluchowski, M. (1908). Molekular-kinetische Theorie der Opaleszenz von Gasen im kritischen Zustande, sowie einiger verwandter Erscheinungen. Annalen der Physik, 25, 205-225.

Spilhaus, A. F. Jr., (1968). Observations of light scattering in seawater. Limnology and Oceanography, 13, 418-422.

Stramska, M., Stramski, D., Hapter, R., Kaczmarek, S., \& Stoń, J. (2003). Bio-optical relationships and ocean color algorithms for the north polar region of the Atlantic. Journal of Geophysical Research, 108(C5), 3143, doi:10.1029/2001JC001195.

Stramski, D. (1994). Gas microbubbles: An assessment of their significance to light scattering in quiescent seas. In J. S. Jaffe (Ed.), Ocean Optics XII. Proceedings SPIE (Vol. 2258, pp. 704-710). Bellingham: The Society of Photo-Optical Instrumentation Engineers.

Stramski, D. (1999). Refractive index of planktonic cells as a measure of cellular carbon and chlorophyll a content. Deep-Sea Research Part I, 46, 335-351.

Stramski, D., Bricaud, A., \& Morel, A. (2001). Modeling the inherent optical properties of the ocean based on the detailed composition of planktonic community. Applied Optics, 40, 2929-2945.

Stramski, D., \& Kiefer, D. A. (1990). Optical properties of marine bacteria. In R. W. Spinrad (Ed.), Ocean Optics X. Proceedings SPIE (Vol. 1302, pp. 250-268). Bellingham: The Society of Photo-Optical Instrumentation Engineers.

Stramski, D., \& Kiefer, D. A. (1991). Light scattering by microorganisms in the open ocean. Progress in Oceanography, $28,343-383$.

Stramski, D., \& Mobley, C. D. (1997). Effects of microbial particles on oceanic optics: A database of single-particle optical properties. Limnology and Oceanography, 42, 538-549.

Stramski, D., \& Piskozub, J. (2003). Estimation of scattering error in spectrophotometric measurements of light absorption by aquatic particles from three-dimensional radiative transfer simulations. Applied Optics, 42, 3634-3646. 
Stramski, D., Reynolds, R. A., Kahru, M., \& Mitchell, B. G. (1999). Estimation of particulate organic carbon in the ocean from satellite remote sensing. Science, 285, 239-242.

Stramski, D., \& Tęgowski, J. (2001). Effects of intermittent entrainment of air bubbles by breaking wind waves on ocean reflectance and underwater light field. Journal of Geophysical Research, 106, 31345-31360.

Stramski, D., Woźniak, S. B., \& Flatau, P. J. (2004). Optical properties of Asian mineral dust suspended in seawater. Limnology and Oceanography, 49, 749-755.

Sugihara, S., Kishino, M., \& Okami, N. (1982). Back-scattering of light by particles suspended in water. Scientific Papers of the Institute of Physical and Chemical Research, 76, 1-8.

Tatarski, V. I. (1961). Wave propagation in a turbulent medium. New York: McGraw-Hill.

Terrill, E. J., Melville, W. K., \& Stramski, D. (2001). Bubble entrainment by breaking waves and their influence on optical scattering in the upper ocean. Journal of Geophysical Research, 106, 16815-16823.

Thorpe, S. A. (1982). On the clouds of bubbles formed by breaking wind-waves in deep water, and their role in air-sea gas transfer. Philosophical Transactions of the Royal Society of London, A304, 155-210.

Tomas, C. R. (Ed.). (1997). Identifying Marine Phytoplankton. San Diego: Academic Press.

Twardowski, M., Boss, E., Macdonald, J. B., Pegau, W. S., Barnard, A. H., \& Zaneveld, J. R. V. (2001). A model for estimating bulk refractive index from the optical backscattering ratio and the implications for understanding particle composition in case I and case II waters. Journal of Geophysical Research, 106, 14129-14142.

Tyler, J. E. (1961). Scattering properties of distilled and natural waters. Limnology and Oceanography, 6, 451-456.

Tyler, J. E., \& Richardson, W. H. (1958). Nephelometer for the measurement of volume scattering function in situ. Journal of the Optical Society of America, 48, 354-357.

Ulloa, O., Sathyendranath, S., \& Platt, T. (1994). Effect of the particle-size distribution on the backscattering ratio in seawater. Applied Optics, 33, 7070-7077.

Vaillancourt, R. D., Brown, C. W., Guillard, R. R. L., \& Balch, W. M. (2004). Light backscattering properties of marine phytoplankton: Relationships to cell size, chemical composition and taxonomy. Journal of Plankton Research, 26, $191-212$. van de Hulst, H. C. (1957). Light scattering by small particles. New York: J. Wiley and Sons.

Verity, P. G., Robertson, C. Y., Tronzo, C. R., Andrews, M. G., Nelson, J. R., \& Sieracki, M. E. (1992). Relationships between cell volume and the carbon and nitrogen content of marine photosynthetic nanoplankton. Limnology and Oceanography, 37, 1434-1446.

Vold, R. D., \& Vold, M. J. (1983). Colloid and Interface Chemistry. London: Addison-Wesley.

Volten, H., de Haan, J. F., Hovenier, J. W., Schreurs, R., Vassen, W., Dekker, A. G., et al. (1998). Laboratory measurements of angular distributions of light scattered by phytoplankton and silt. Limnology and Oceanography, 43, 1180-1197.

Voss, J. M., \& Smart, J. H. (1994). Optical backscattering measurements off the coast of Hawaii. In J. S. Jaffe (Ed.), Ocean Optics XII. Proceedings SPIE (Vol. 2258, pp. 116-122). Bellingham: The Society of Photo-Optical Instrumentation Engineers.

Voss, K. J., Balch, W. M., \& Kilpatrick, K. A. (1998). Scattering and attenuation properties of Emiliania huxleyi cells and their detached coccoliths. Limnology and Oceanography, 43, 870-876.

Voss, K. J., \& Fry, E. S. (1984). Measurement of the Mueller matrix for ocean water. Applied Optics, 23, $4427-4439$.

Wells, M. L., \& Goldberg, E. D. (1991). Occurrence of small colloids in sea water. Nature, 353, 342-344.

Wells, M. L., \& Goldberg, E. D. (1994). The distribution of colloids in the North Atlantic and Southern Oceans. Limnology and Oceanography, 39, 286-302.

Wells, W. H. (1973). Theory of small angle scattering. In Electromagnetics of the Sea, AGARD conference proceedings (Vol. 81, pp. 3.31-3.3-19). Neuilly-Sur-Seine: NATO.

Witkowski, K., Król, T., Zieliński, A., \& Kuteń, E. (1998). A light-scattering matrix for unicellular marine phytoplankton. Limnology and Oceanography, 43, 859-869.

Yamasaki, A., Fukuda, H., Fukuda, R., Miyajima, T., Nagata, T., Ogawa, H., et al. (1998). Submicrometer particles in northwest Pacific coastal environments: Abundance, size distribution, and biological origins. Limnology and Oceanography, 43, 536-542.

Zaneveld, J. R. V., \& Kitchen, J. C. (1995). The variation in the inherent optical properties of phytoplankton near an absorption peak as determined by various models of cell structure. Journal of Geophysical Research, 100, 13309-13320.

Zaneveld, J.R.V., Pegau, S. \& Mueller, J.L. (2003). Volume scattering function and backscattering coefficients: Instruments, characterization, field measurements and data analysis protocols. In J. L Mueller, G. S. Fargion \& C. R. McClain (Eds.), Ocean optics protocols for satellite ocean color sensor validation, revision 4, Vol. IV: Inherent optical properties: instruments, characterization, field measurements and data analysis protocols, NASA Tech. Memo., 2003-211621/Rev4-Vol.IV (pp. 65-76). Greenbelt: NASA Goddard Space Flight Center.

Zaneveld, J. R. V., Roach, D. M., \& Pak, H. (1974). The determination of the index of refraction distribution of oceanic particulates. Journal of Geophysical Research, 79, 4091-4095.

Zhang, X., Lewis, M., \& Johnson, B. (1998). Influence of bubbles on scattering of light in the ocean. Applied Optics, $37,6525-6536$.

Zhang, X., Lewis, M., Lee, M., Johnson, B., \& Korotaev, G. (2002). The volume scattering function of natural bubble populations. Limnology and Oceanography, 47, 1273-1282. 
Zieliński, A., Król, T., \& Gędziorowska, D. (1987). The influence of the inner structure of the Chlorella vulgaris cell on light scattering properties. Bulletin of the Polish Academy of Sciences, Earth Sciences, 35, 119-125.

Zieliński, A., Król, T., Gędziorowska, D., \& Woliński, L. (1986). Theoretical and experimental investigations into light scattering by the Chlorella vulgaris cell. Bulletin of the Polish Academy of Sciences, Earth Sciences, 34, 313-319. 